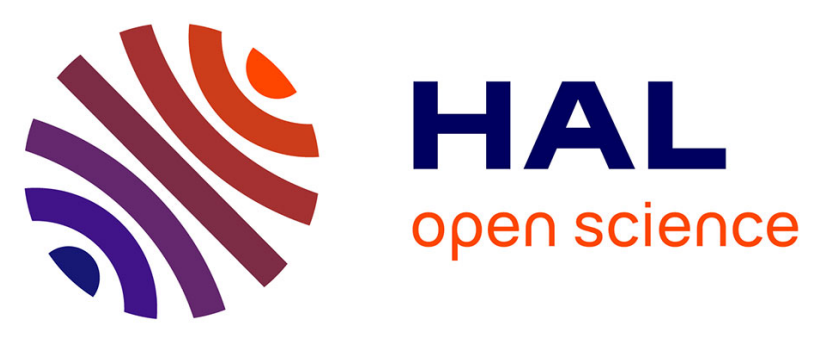

\title{
Readily Accessible Unsymmetrical Unsaturated 2,6-Diisopropylphenyl N-Heterocyclic Carbene Ligands. Applications in Enantioselective Catalysis
}

Robert Tarrieu, Adrien Dumas, Jompol Thongpaen, Thomas Vives, Thierry

Roisnel, Vincent Dorcet, Christophe Crevisy, Olivier Baslé, Marc Mauduit

\section{To cite this version:}

Robert Tarrieu, Adrien Dumas, Jompol Thongpaen, Thomas Vives, Thierry Roisnel, et al.. Readily Accessible Unsymmetrical Unsaturated 2,6-Diisopropylphenyl N-Heterocyclic Carbene Ligands. Applications in Enantioselective Catalysis. Journal of Organic Chemistry, 2017, 82 (4), pp.1880-1887. 10.1021/acs.joc.6b02888. hal-01475697

HAL Id: hal-01475697

https://hal-univ-rennes1.archives-ouvertes.fr/hal-01475697

Submitted on 4 Jul 2017

HAL is a multi-disciplinary open access archive for the deposit and dissemination of scientific research documents, whether they are published or not. The documents may come from teaching and research institutions in France or abroad, or from public or private research centers.
L'archive ouverte pluridisciplinaire HAL, est destinée au dépôt et à la diffusion de documents scientifiques de niveau recherche, publiés ou non, émanant des établissements d'enseignement et de recherche français ou étrangers, des laboratoires publics ou privés. 


\title{
Readily Accessible Unsymmetrical Unsaturated 2,6- Diisopropylphenyl-N-Heterocyclic Carbene Ligands. Applications in Enantioselective Catalysis.
}

\author{
Robert Tarrieu, ${ }^{a}$ Adrien Dumas, ${ }^{a}$ Jompol Thongpaen, ${ }^{a}$ Thomas Vives, ${ }^{a}$ Thierry \\ Roisnel, ${ }^{b}$ Vincent Dorcet, ${ }^{b}$ Christophe Crévisy, ${ }^{* a}$ Olivier Baslé, ${ }^{* a}$ and Marc Mauduit*a \\ ${ }^{a}$ Ecole Nationale Supérieure de Chimie de Rennes, CNRS UMR 6226, Institut des \\ Sciences Chimiques de Rennes, 11 Allée de Beaulieu, 35708 Rennes Cedex 7 \\ (France), \\ e-mail: christophe.crevisy@ensc-rennes.fr \\ olivier.basle@ensc-rennes.fr \\ marc.mauduit@ensc-rennes.fr \\ ${ }^{b}$ Université de Rennes 1, CNRS, UMR 6226, Institut des Sciences Chimiques de \\ Rennes, Centre de Diffractométrie X, Bat 10B, Campus de Beaulieu, 35042 Rennes \\ Cedex (France)
}

\section{Graphical Abstract:}

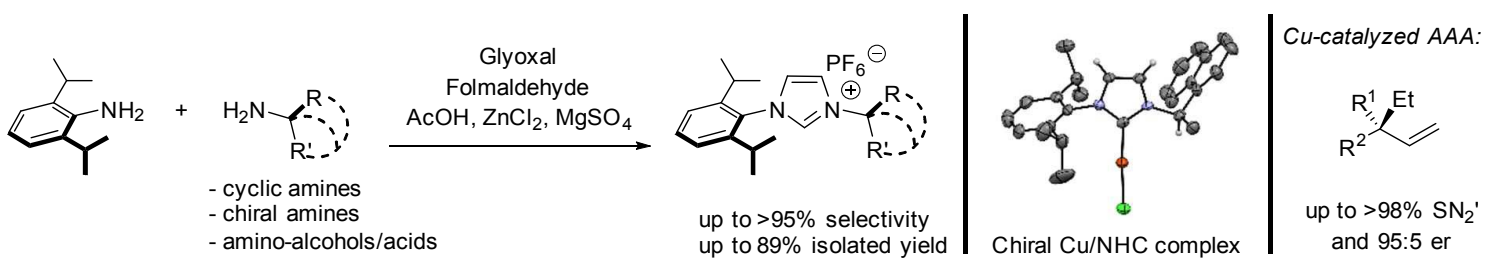

\begin{abstract}
A new multicomponent procedure was applied to the synthesis of (a)chiral bulky unsymmetrical unsaturated 2,6-diisopropylphenyl-N-heterocyclic carbene (NHC) precursors with excellent selectivity (up to 95\%) and good yields. This approach offers access to new chiral NHCs ligands, which found successful applications in both copper-catalyzed asymmetric allylic alkylation and coppercatalyzed asymmetric borylation.
\end{abstract}




\section{Introduction}

During the past two decades, N-Heterocyclic Carbenes (NHCs) have broken through in the field of coordination chemistry. ${ }^{1}$ These species have been used as ligands to kinetically stabilize highly reactive, low-valent transition metals complexes and enable high catalytic activity to be achieved. ${ }^{2}$ Among the large variety of NHCs described in the literature, $\mathrm{C}_{2}$-symmetrical ligands bearing the sterically encumbered 2,6-diisopropylphenyl (Dipp) nitrogen substituent, i.e. bis(2,6diisopropylphenyl)imidazol-2-ylidene (IPr) and bis(2,6-diisopropylphenyl) imidazolidin2-ylidene (SiPr), have on numerous occasions demonstrated significant benefits in multiple modern chemistry applications. ${ }^{3}$ On the other hand, unsymmetrical NHCs with increased steric discrimination and distinctive electronic properties have witnessed growing interest in the recent years. ${ }^{4}$ Indeed, transition metal bearing Dipp-based unsymmetrical NHC have found considerable advantages in terms of reactivity and selectivity towards challenging processes. ${ }^{5,6}$ A related type of carbene ligand, the family of cyclic(alkyl)(amino)carbenes (CAACs) developed by Bertrand and coworkers, has allowed important achievements by stabilizing unusual both transition metal and main group element complexes. ${ }^{7}$ However, the strategies to construct unsymmetrical NHC precursors require multiple steps syntheses that, due to time consumption and cost, may limit their industrial applications. ${ }^{8}$ Recently, we described an elegant and practical multicomponent strategy, providing access to various unsymmetrical unsaturated (a)chiral N-heterocyclic carbene $\left(\mathrm{U}_{2}-\mathrm{NHC}\right)$ ligands precursors with high selectivity and good yield. ${ }^{9}$ Indeed, by simply mixing an arylamine, an alkylamine, formaldehyde and glyoxal in acetic acid for few minutes, a wide range of imidazolium salts were obtained with high selectivity (up to 93\%). The corresponding $\mathrm{U}_{2}-\mathrm{NHC}$ ligands were evaluated and evidenced strong electron donor 
ability, high steric discrimination, and modular steric demand. This methodology was also successfully applied for the construction of chiral bidentate hydroxyalkyl- and carboxyalkyl-NHC ligands, which demonstrated excellent transfer of the stereoinduction from the chiral center to the metal. ${ }^{10}$ Despite the efficiency and flexibility of this multicomponent procedure, the introduction of highly hindered pattern such as the Dipp fragment appeared as a major limitation, affording the desired bulky $\mathrm{U}_{2}-\mathrm{NHC}$ precursors with poor yields and selectivities. ${ }^{9,10}$ Herein, we disclose a novel multicomponent procedure leading to a wide range of (a)chiral unsymmetrical unsaturated 1-(2,6-diisopropylphenyl)-3-alkyl-imidazolium salts with high selectivities (up to $95 \%$ ) and good yields (figure 1). Moreover, evaluation of this ligand family in copper catalysis demonstrated utility in asymmetric C-B and C-C bond formation.

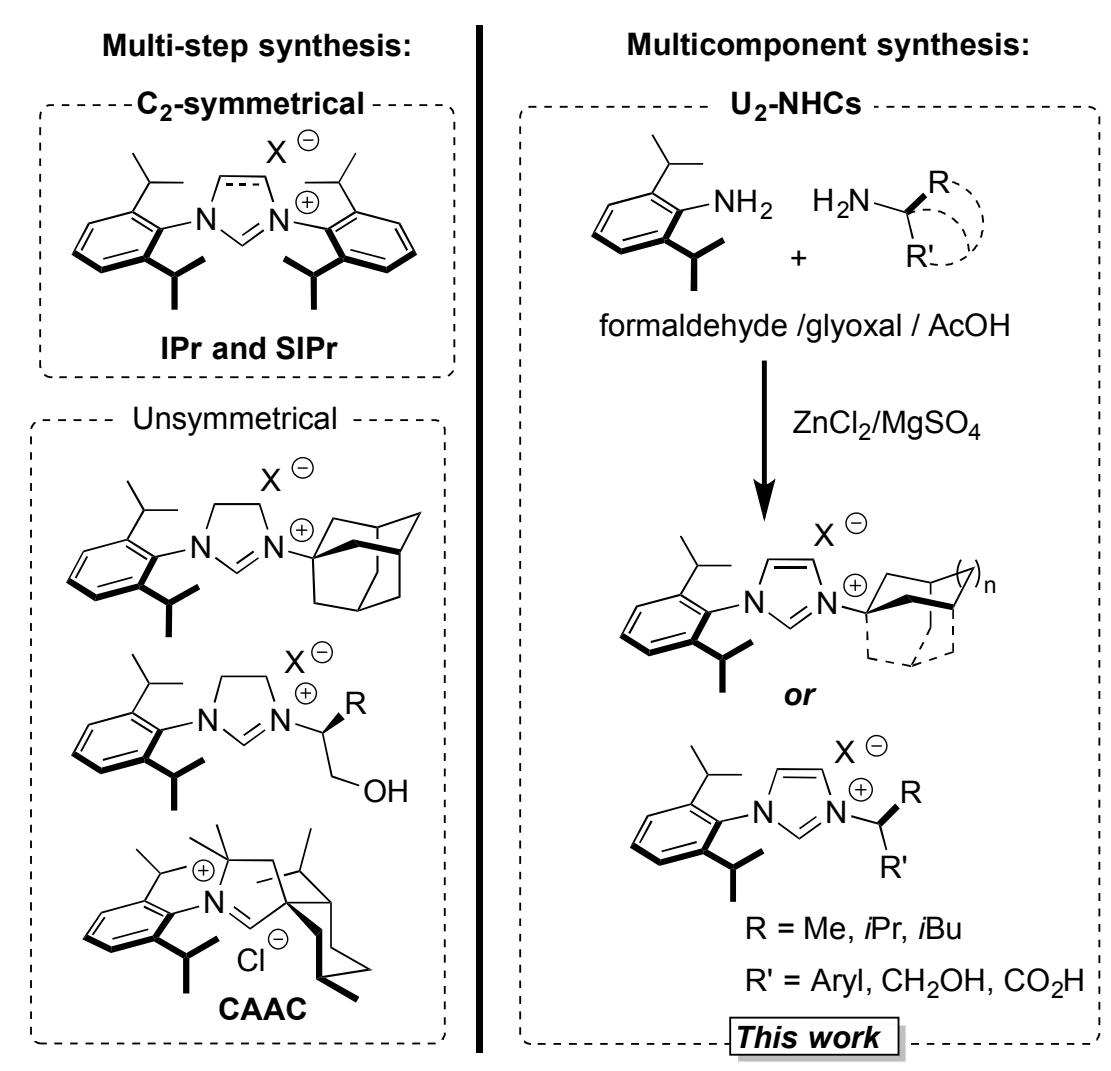

Figure 1. Examples of Dipp-based NHC ligands (left) and new synthetic route to Dipp-based $\mathrm{U}_{2}-\mathrm{NHC}$ ligands (right) 


\section{Results and Discussion}

With the objective to reach the exclusive formation of the unsymmetrical 1(2,6-diisopropylphenyl)-3-cycloalky-imidazolium salts 3 , we decided to re-investigate our initial multicomponent procedure by probing various reaction conditions (Table 1). An important point to be taken into consideration when using 2,6-diisopropylaniline (1) in such approach, is the inherent low reactivity of this sterically congested amine under typical operational conditions for the synthesis of imidazolium salts. ${ }^{11}$ First, using cyclododecanamine as the second partner of the reaction, the modest selectivity and poor yield observed at $40^{\circ} \mathrm{C}$ were improved with a slight increase of the temperature to $60^{\circ} \mathrm{C}$ (Table 1 , entries 1-2). Importantly, a major improvement in both selectivity and yield could be obtained after addition of a stoichiometric amount of hydrochloric acid (Table 1 , entry 4 ). ${ }^{12}$ During the screening of Lewis acids, the addition of zinc chloride (1 equiv.) in diethylether appeared highly beneficial affording the unsymmetrical NHC precursors with very high selectivity (>95\%) and excellent NMR yield (Table 1 , entry 7 ). ${ }^{13}$ Interestingly, without affecting selectivity, the addition of magnesium sulfate $\left(\mathrm{MgSO}_{4}\right)$ could improve the NMR yield to $>95 \%$ and allowed isolation of the 1-(2,6-diisopropylphenyl)-3-cyclodedecyl-imidazolium salt $3 \mathbf{a}$ in $76 \%$ yield (table 1 , entry 9). Finally, replacement of the $\mathrm{BF}_{4}^{-}$anion by $\mathrm{PF}_{6}^{-}$facilitated the purification procedure and afforded the corresponding imidazolium. $\mathrm{PF}_{6}$ salts with high $89 \%$ isolated yield (table 1 , entry 10 ).

Table 1. Optimization of the conditions for the multicomponent process. 


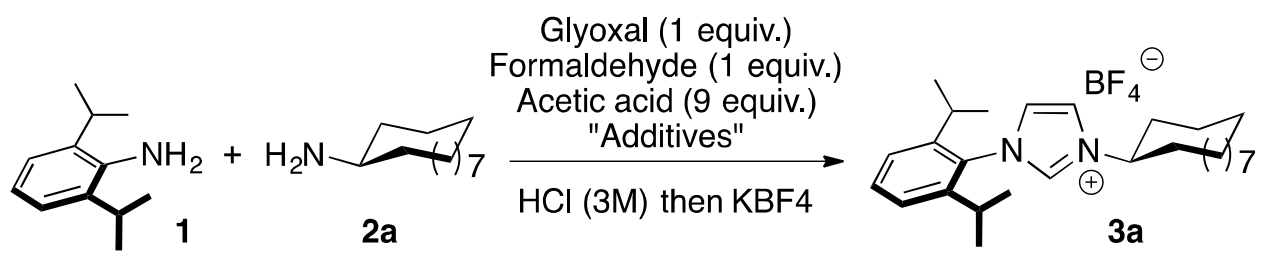

\begin{tabular}{|c|c|c|c|c|}
\hline Entry & Additives & $\mathrm{T}\left({ }^{\circ} \mathrm{C}\right)$ & Selectivity $(\%)^{a}$ & Yield $(\%)^{\mathrm{b}}$ \\
\hline 1 & $N A^{c}$ & 40 & 57 & 35 \\
\hline 2 & $N A^{c}$ & 60 & 69 & 51 \\
\hline 3 & $\mathrm{HCl}(1 \mathrm{~mol} \%)^{\mathrm{d}}$ & 60 & 73 & 57 \\
\hline 4 & $\mathrm{HCl}(1 \text { equiv. })^{\mathrm{d}}$ & 60 & 89 & 89 \\
\hline 5 & $\mathrm{MgCl}_{2}(\mathrm{~s})$ (1 equiv.) & 60 & 88 & 73 \\
\hline 6 & $\mathrm{ZnCl}_{2}(\mathrm{~s})$ (1 equiv.) & 60 & 93 & 83 \\
\hline 7 & $\mathrm{ZnCl}_{2}(1 \text { equiv. })^{\mathrm{d}}$ & 60 & $>95$ & 88 \\
\hline 8 & $\mathrm{ZnCl}_{2}(1.2 \text { equiv. })^{d}$ & 60 & $>95$ & 94 \\
\hline 9 & $\begin{array}{l}\mathrm{MgSO}_{4}(2 \text { equiv. }), \mathrm{ZnCl}_{2}(1.2 \\
\text { equiv. })^{\mathrm{d}}\end{array}$ & 60 & $>95$ & $>95(76)$ \\
\hline $10^{\mathrm{e}}$ & $\begin{array}{l}\mathrm{MgSO}_{4}(2 \text { equiv. }), \mathrm{ZnCl}_{2}(1.2 \\
\text { equiv. })^{\mathrm{d}}\end{array}$ & 60 & $>95$ & $>95(89)$ \\
\hline 11 & $\mathrm{MgSO}_{4}$ (2 equiv.) & 60 & 65 & 46 \\
\hline 12 & $\mathrm{Et}_{2} \mathrm{O}$ & 60 & 45 & 30 \\
\hline \multicolumn{5}{|c|}{$\begin{array}{l}{ }^{a} \text { Determined by }{ }^{1} \mathrm{H} \text { NMR using tetrachloroethane as an internal standard. }{ }^{b} \mathrm{NMR} \\
\text { yields using tetrachloroethane as an internal standard; Isolated yields presented in } \\
\text { parentheses. }{ }^{\mathrm{c}} \text { Not applicable. }{ }^{\mathrm{d}} 1 \mathrm{M} \text { in } \mathrm{Et}_{2} \mathrm{O} .{ }^{\mathrm{e}} \mathrm{KPF}_{6} \text { was used instead of } \mathrm{KBF}_{4} \text {. }\end{array}$} \\
\hline
\end{tabular}

Under the optimized reaction conditions, we extended the scope of the reaction using first a variety of cycloalkylamines (Scheme 1). Similarly to the results 
obtained with cyclododecanamine, the desired $\mathrm{U}_{2}-\mathrm{NHC}$ precursors bearing the cyclooctyl-, cyclopentyl- fragments were obtained with excellent selectivity and good isolated yields. Interestingly, the polycyclic adamantylamine could be efficiently employed in this strategy and afforded perfect selectivity in the preparation of $\mathbf{3 e}$; the unsaturated analogue of the most effective NHC ligand precursor employed in ruthenium-catalyzed Z-selective metathesis. ${ }^{5}$ Moreover, while cyclobutylamine reacted quite smoothly ( $86 \%$ selectivity and $66 \%$ isolated yield), a noticeable decrease of selectivity was observed with cyclopropylamine leading to a modest $42 \%$ isolated yield of the corresponding imidazolium salt $\mathbf{3 f}$. Importantly, this approach was also applicable to the use of alpha substituted chiral amines such as $(S)$ - $\alpha$ methylbenzylamine, $\quad(R)-1-(1-$ naphthyl)ethylamine, $\quad(1 R, \quad 2 R, \quad 3 R, \quad 5 S)$ isopinocampheylamine and $(R)$-indanamine allowing for a simple and efficient access to bulky chiral NHC precursors with strong propensity for new applications in selective catalysis (figure 2). ${ }^{14,5 g}$ In effort to further extend the synthetic utility of this multicomponent procedure, the synthesis of chiral bidentate NHC ligand precursors was investigated. Pleasantly, the bulky chiral imidazolium salts $\mathbf{3 k}$ and $\mathbf{3} \mathbf{I}$ derived from (L)-leucinol and (L)-valinol were formed with excellent selectivity and isolated in reasonable yields. Under the same conditions, modest selectivity and isolated yield could be obtained with (L)-leucine.

Scheme 1. Scope of the multicomponent procedure. 


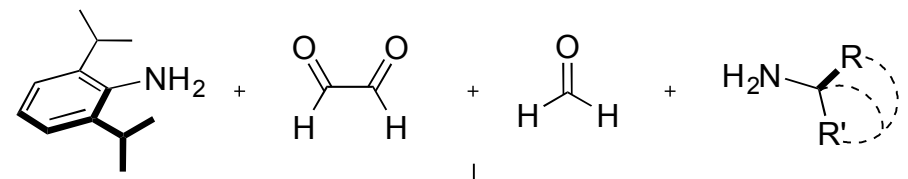

$\mathrm{AcOH}, \mathrm{ZnCl}_{2}, \mathrm{MgSO}_{4}$, $60{ }^{\circ} \mathrm{C}, 25 \mathrm{~min}$, then $\mathrm{HCl} 3 \mathrm{M}$ and $\mathrm{KX}$

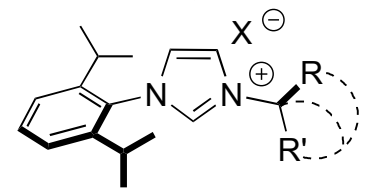

(Selectivity $^{\mathrm{a}} /$ Yield $^{\mathrm{b}}$ )
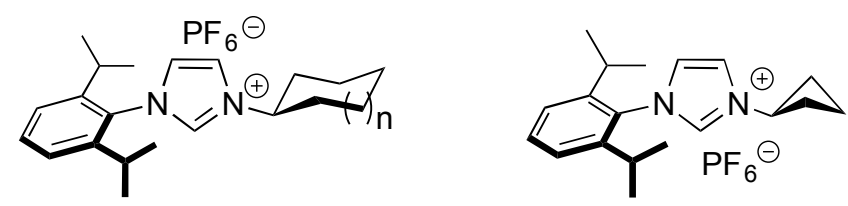

$$
\begin{array}{ll}
\mathrm{n}=7 & \mathbf{3 a}(>95 \% / 89 \%) \\
\mathrm{n}=3 & \mathbf{3 b}(91 \% / 70 \%)
\end{array}
$$$$
\mathrm{n}=0 \quad 3 \mathrm{c}(>95 \% / 78 \%)
$$

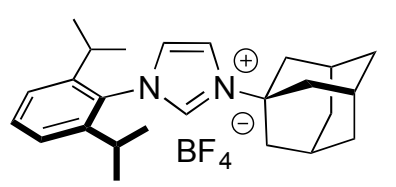

$$
3 e-B_{4}(94 \% / 75 \%)^{c}
$$

3d $(86 \% / 66 \%)$<smiles>CC(C)c1cccc(C(C)C)c1-n1cc[n+]([C@H](C)c2ccccc2)c1</smiles>

3g $(94 \% / 71 \%)$<smiles></smiles><smiles>CC(C)c1cccc(C(C)C)c1-n1cc[n+](C2CC2)c1</smiles>

3f $(70 \% / 42 \%)$
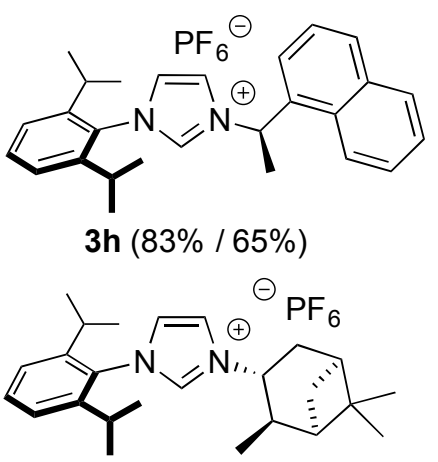

3j (91\% / 51\%)

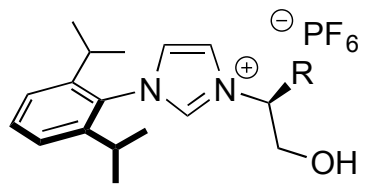

3k: $\mathrm{R}=\mathrm{i}-\mathrm{Bu}(91 \% / 65 \%)$ 3I: $R=i-\operatorname{Pr}(93 \% / 46 \%)$

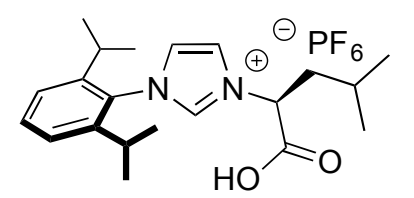

$3 \mathrm{~m}(66 \% / 37 \%)$

a Determined by ${ }^{1} \mathrm{H}$ NMR analysis. ${ }^{b}$ Isolated Yields. ${ }^{c}$ The purification procedure is facilitated with $\mathrm{BF}_{4}{ }^{-}$instead of $\mathrm{PF}_{6}{ }^{-}$. 


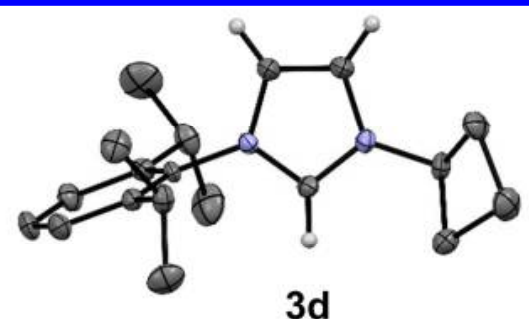

3d

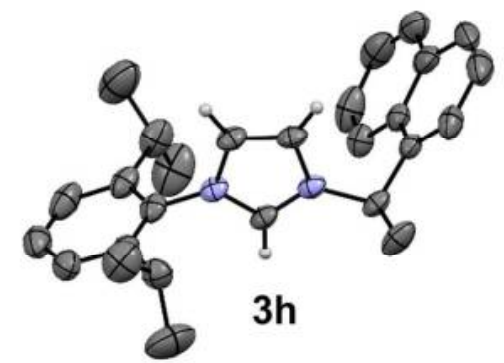

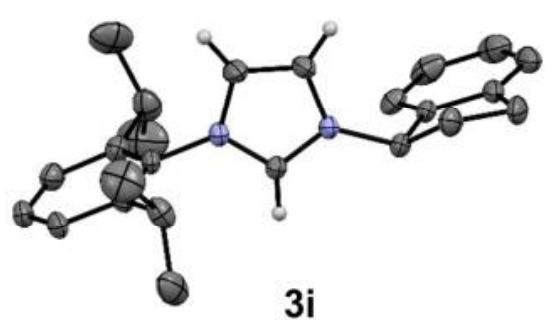

$3 \mathbf{i}$

Figure 2. Solid-state structure of a selection of imidazolium salts from single crystal X-ray diffraction. Displacement ellipsoids are drawn at 50\% probability. Most hydrogen atoms and $\mathrm{PF}_{6}$ anions have been omitted for clarity ( $\mathrm{N}$ in blue, $\mathrm{C}$ in grey, $\mathrm{P}$ in orange, $\mathrm{F}$ in yellow, $\mathrm{H}$ in white.

In order to get a better understanding of the reaction mechanism and to provide insight into the factors governing the selectivity of the multicomponent procedure, we decided to adopt a two-step approach. Importantly, preliminary experiments demonstrated that the procedure involving the combination of $\mathrm{DippNH}_{2}$ 1 and adamantylamine $2 \mathrm{a}$ could be greatly simplified, since $\mathrm{ZnCl}_{2}$ and $\mathrm{MgSO}_{4}$ additives had no significant impact on the outcomes of this specific reaction. ${ }^{15}$ Therefore, this simplified protocol was selected as a model for the following mechanistic study. First, a stoichiometric amount of $\mathrm{DippNH}_{2}$ 1, $\mathrm{AdNH}_{2}$ 2a and aqueous glyoxal were reacted in presence of an excess of acetic acid (9 equiv.). The ${ }^{1} \mathrm{H}$ NMR analysis of the resulting crude mixture $(<5$ min reaction) showed the preferential formation of the diaryl-diimine 4 (>95\%) without unequivocal identification 
of diimine 5 and no detectable amount of dialkyl-diimine 6 (Scheme 2, A). ${ }^{16}$ The subsequent addition of 1 equivalent of aqueous formaldehyde afforded the desired unsymmetrical imidazolium salt 3 e-OAc with high $>95 \%$ selectivity along with $<5 \%$ of the symmetrical dialkyl imidazolium salt 7e-OAc and no detectable amount of the IPr imidazolium salt precursors (scheme 2, B). Besides, it was observed that the sterically congested diaryl-diimine $\mathbf{4}$ was poorly reactive towards cyclisation under our reactions conditions, whereas the dialkyl-diimine 6 was able to afford easily the corresponding cyclized imidazolium salt 7 e-OAc. ${ }^{16}$ Nevertheless, when the cyclisation of the dialkyl-diimine 6 was performed in the presence of $\mathrm{DippNH}_{2} \mathbf{1}$ (2 equiv.), the major product was the unsymmetrical salt 3e-OAc (3e-OAc/7e-OAc ratio $=94: 6) .{ }^{16}$ Consequently, the high selectivity in favor of the unsymmetrical salt $3 e-$ OAc may be explained by the fact that the cyclizations of the symmetrical diimines are slower than i) the equilibration reactions between the three diimines ${ }^{17}$ and ii) than the cyclisation of the unsymmetrical diimine $\mathbf{5}^{18}$

Scheme 2. Mechanistic investigation of unsymmetrical salts synthesis. (A) Ratio in diimines after condensation with aqueous glyoxal and excess acetic acid $(<5$ min reaction). (B) Selectivity of the cyclization procedure in presence of aqueous formaldehyde. ${ }^{a}$ Not identified ${ }^{b}$ not detected 
A

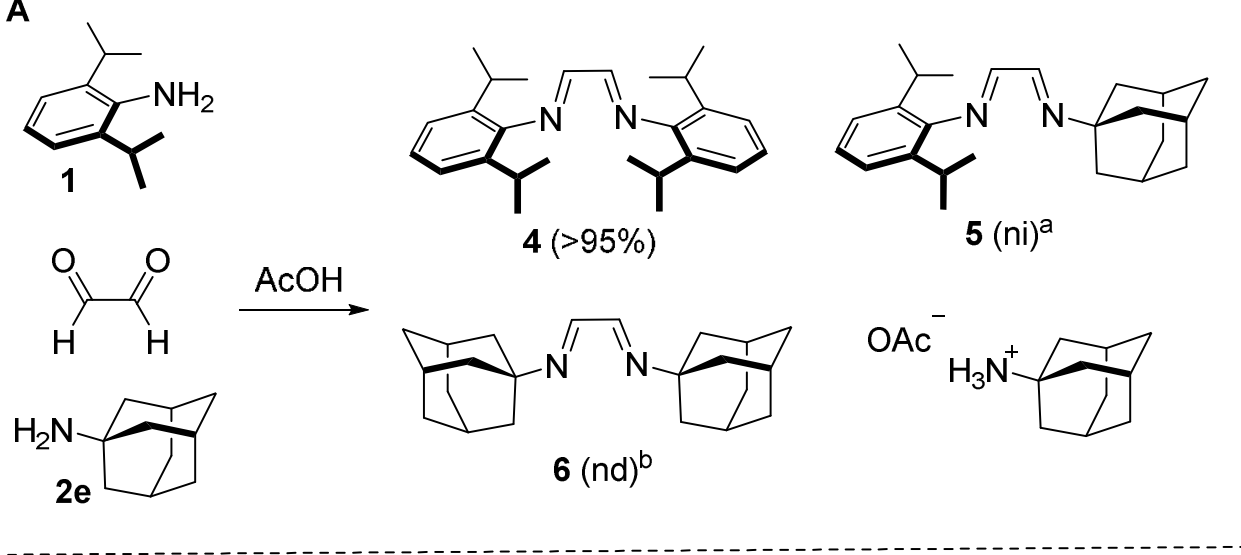

B
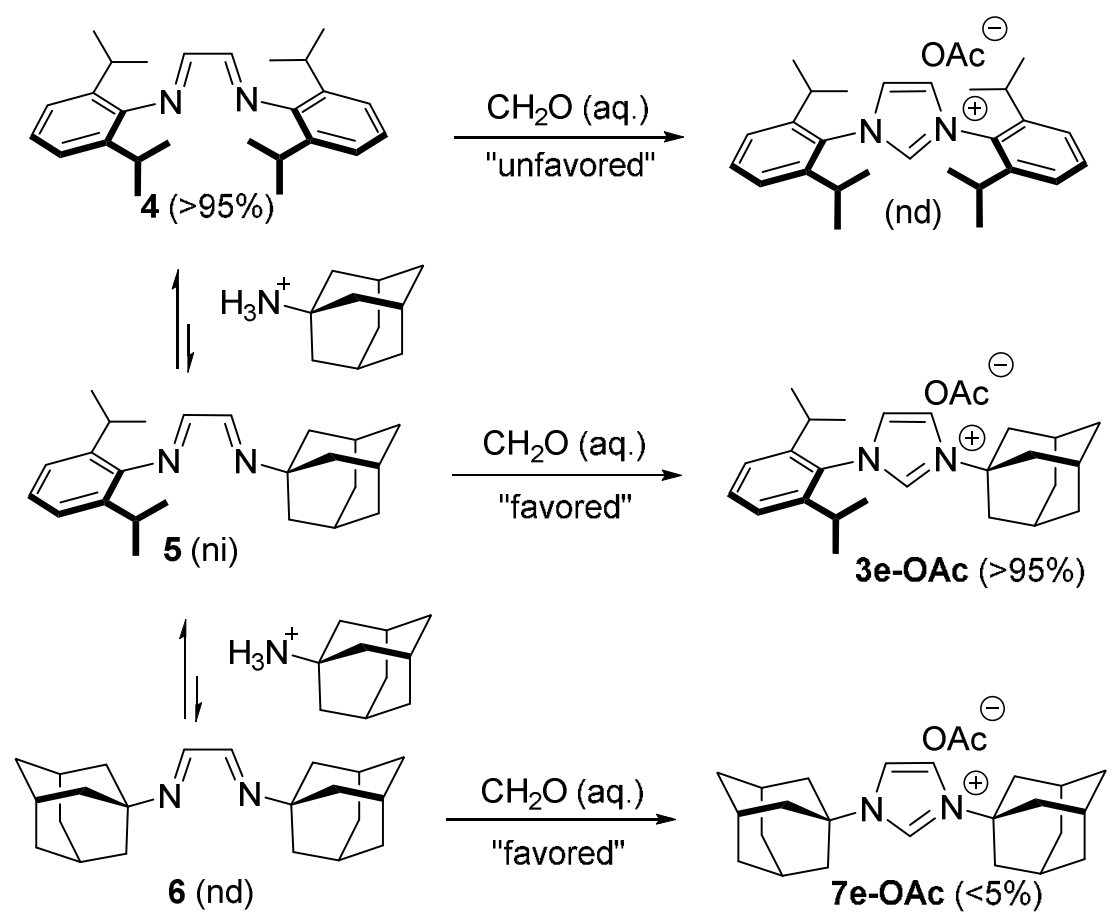

The asymmetric conjugate addition of nucleophiles to electron deficient alkenes represents one of the most powerful methods to form $\mathrm{C}-\mathrm{C}$ and $\mathrm{C}$ heteroelement bond. ${ }^{19}$ In the recent years, enantioselective conjugate addition of diboron reagents to $\alpha, \beta$-unsaturated carbonyl compounds catalyzed by Cu-based $\mathrm{NHC} /$ complexes has attracted considerable interest. ${ }^{20}$ With our new series of unsymmetrical chiral imidazolium salts in hand, we decided to evaluate their potential as chiral ligands in copper-catalyzed borate addition to ethyl cinnamate (8). The 
chiral NHC precursor $3 \mathrm{~h}$ displaying demanding steric environment was initially selected and the in situ generated $\mathrm{Cu} / \mathrm{NHC}$ complex afforded the desired product 9 in good $67 \%$ isolated yield and $87: 13$ enantiomeric ratio (scheme 3 ). On the other hand, the use of the $\mathrm{C}_{2}$ symmetrical ligand precursor analogue $7 \mathrm{~h}$ allowed for poor enantiocontrol (67.5:32.5 er), which demonstrates unambiguously the advantage provided by the sterically congested unsymmetrical chiral ligand. Moreover, it should be noted that the isolated and fully characterized, including X-ray diffraction analysis, $\mathrm{Cu} / \mathrm{NHC}$ complex $3 \mathrm{~h}-\mathrm{CuCl}$ catalyzed efficiently the transformation to form product $\mathbf{9}$ with $82: 18$ enantiomeric ratio. ${ }^{21}$

Scheme 3. Copper/NHC-Catalyzed asymmetric borylation. ${ }^{a}$
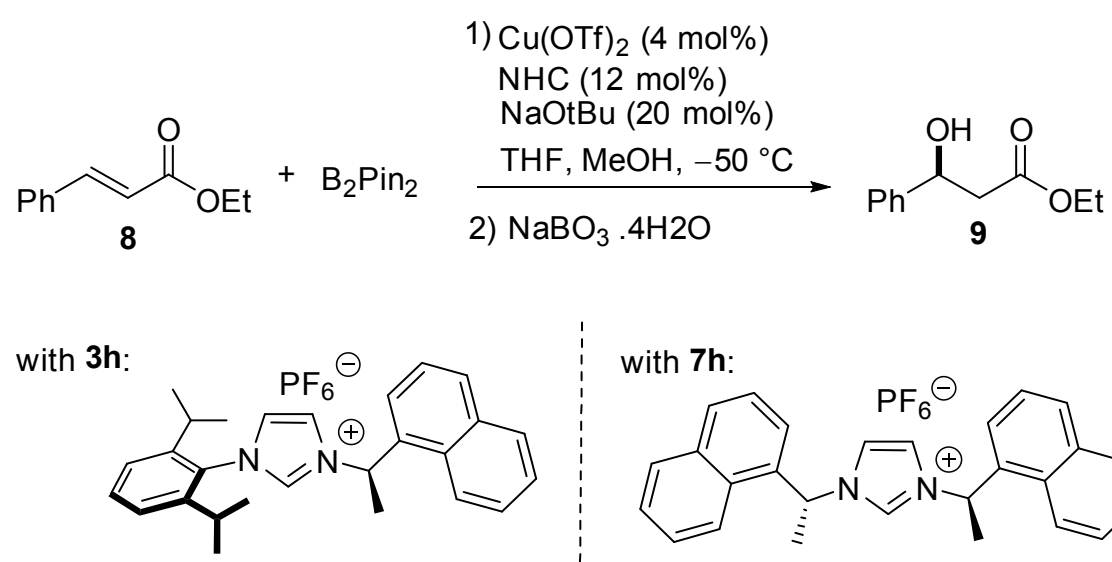
with $7 \mathbf{h}$ :

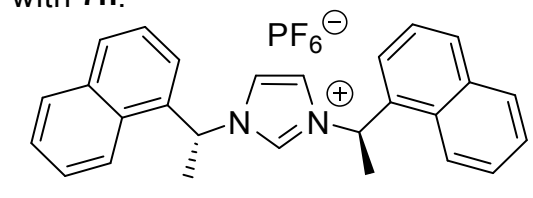

$67 \%$ yield, $87: 13$ er

$60 \%$ yield, 67.5:32.5 er

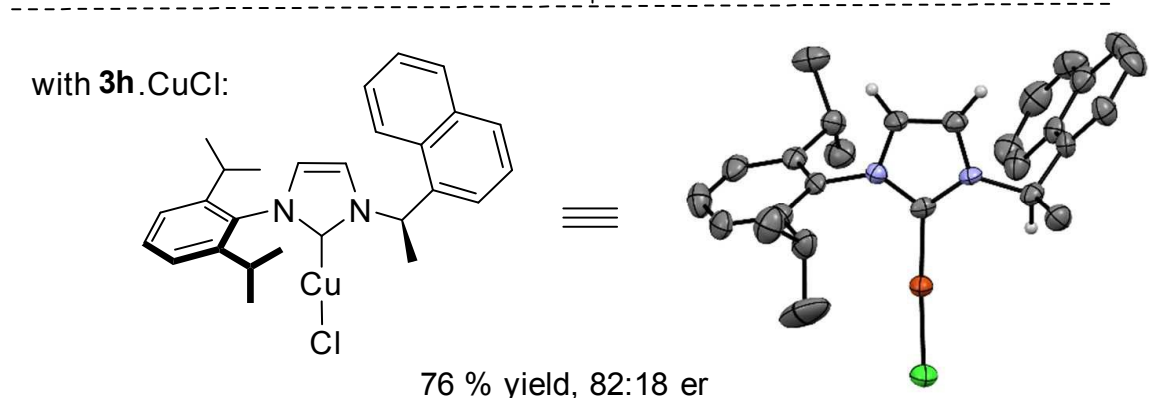

${ }^{a}$ Enantiomeric ratios were obtained from chiral HPLC analysis. 
To further demonstrate the potential of newly developed ligand family, the chiral bidentate hydroxyalkyl ligand precursor $\mathbf{3 k}$ was evaluated in copper-catalyzed asymmetric allylic alkylation to form all-carbon quaternary centers. ${ }^{6 c, 10}$ Interestingly the catalytic system prepared in situ by deprotonation of the imidazolium salt $\mathbf{3 k}$ with $n$-butyllithium in presence of copper $(\mathrm{I})$ triflate promoted efficiently the reaction between diethylzinc and allylphosphates 10 to form the desired quaternary carbon centers with excellent regio- ( $\left.>96 \% \mathrm{SN}_{2}{ }^{\prime}\right)$ and high enantio-selectivity (up to $95: 5$ er) (Scheme 4).

Scheme 4. Copper-catalyzed AAA with allylphosphates. ${ }^{a, b}$

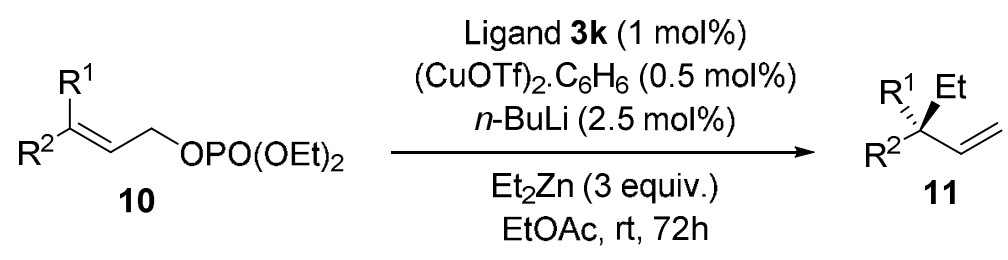

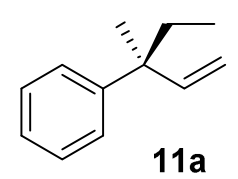

conv: $>95 \%$; Yield: $73 \%$ $96 \% \mathrm{SN}_{2}^{\prime} ; 92: 8 \mathrm{er}$

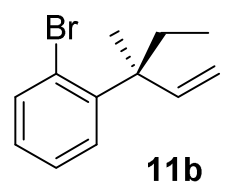

conv: $>95 \%$; Yield: $68 \%$ $>98 \% \mathrm{SN}_{2}{ }^{\prime} ; 91: 9 \mathrm{er}$

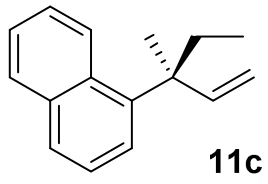

conv: $78 \%$; Yield: $71 \%$ $96 \% \mathrm{SN}_{2}^{\prime} ; 95: 5 \mathrm{er}$

${ }^{\text {a }}$ Conversions and $\mathrm{SN}_{2}$ ' ratios were determined by ${ }^{1} \mathrm{H}$ NMR analysis of the crude mixture. ${ }^{b}$ Enantiomeric ratios were obtained from GC and HPLC analysis of the substitution product. 
In conclusion, a multicomponent synthesis of sterically congested unsymmetrical unsaturated imidazolium salts has been developed. This practical, low cost and efficient methodology allows for the preparation in high yields and high selectivities of a large variety of $\mathrm{NHC}$ ligand precursors bearing the sterically hindered 2,6-diisopropylphenyl moieties. The new chiral monodentate ligands have found application in copper catalyzed asymmetric boronate conjugate addition to unsaturated esters. Significantly, with unsymmetrical chiral monodentate ligand, the chirality transfer is enhanced by the presence of the 2,6-diisopropylphenyl fragment. Moreover, the multicomponent procedure was also successfully applied for the construction of chiral bidentate ligands, which demonstrated excellent control in copper-catalyzed allylic substitution with allyl phosphates to form all-carbon quaternary centers with high regio- and enantioselectivities. The use of this ligand family to construct new transition-metal catalysts along with their applications in asymmetric transformations is currently under intensive investigation in our laboratory and will be reported in due course.

\section{Experimental section}

General Experimental Procedures. All commercial chemicals were used as received unless otherwise noted. 1,4-Bis(2,6-diisopropylphenyl)-1,4-diaza-1,3butadiene $^{11 a} 4$ and N,N'-Bis(1-adamantyl)ethanediimine ${ }^{22} 6$ were obtained following already described procedures. Reactions were monitored by thin-layer chromatography (TLC) carried out on silica gel plates (60F254) using UV light as visualizing agent, $\mathrm{KMnO}_{4} / \mathrm{K}_{2} \mathrm{CO}_{3} / \mathrm{NaOH}$ in water for staining. Column chromatography was performed with Silica Gel (spherical, particle size $40 \mu \mathrm{m}$, neutral). The eluents employed are reported as volume (volume percentages). 
Melting points were measured on a standard melting point apparatus in open capillary tubes and are uncorrected. Optical rotations were recorded on a polarimeter and are uncorrected. ${ }^{1} \mathrm{H}(400 \mathrm{MHz}),{ }^{13} \mathrm{C}(101 \mathrm{MHz}),{ }^{19} \mathrm{~F}(376 \mathrm{MHz}),{ }^{31} \mathrm{P}(162 \mathrm{MHz})$ and ${ }^{11} \mathrm{~B}(128 \mathrm{MHz})$ NMR spectra were recorded on a NMR spectrometer with complete proton decoupling for nucleus other than ${ }^{1} \mathrm{H}$. Chemical shifts are reported in parts per million with the solvent resonance as the internal standard $\left(\mathrm{CDCl}_{3},{ }^{1} \mathrm{H}: \delta\right.$ 7.26 ppm, ${ }^{13} \mathrm{C}: \delta 77.16$ ppm; $\left.\mathrm{CD}_{3} \mathrm{OD},{ }^{1} \mathrm{H}: \delta 3.31 \mathrm{ppm},{ }^{13} \mathrm{C}: \delta 49.00 \mathrm{ppm}\right) ;{ }^{19} \mathrm{~F}$ chemical shifts are reported with $\mathrm{CFCl}_{3}(\delta=0.0 \mathrm{ppm})$ as the internal standard; ${ }^{31} \mathrm{P}$ chemical shifts are reported with $\mathrm{H}_{3} \mathrm{PO}_{4}(\delta=0.0 \mathrm{ppm})$ as the internal standard; ${ }^{11} \mathrm{~B}$ chemical shifts are reported with $\mathrm{BF}_{3} \cdot \mathrm{Et}_{2} \mathrm{O}(\delta=0.0 \mathrm{ppm})$ as the internal standard. Coupling constants $(J)$ are reported in Hertz $(\mathrm{Hz})$. Multiplicities are reported using following abbrevations: $s=$ singlet, br. $s=$ broad singlet, $d=$ doublet, $d d=$ double doublet, $\mathrm{ddd}=$ double double doublet, $\mathrm{dt}=$ double triplet, $\mathrm{t}=$ triplet, $\mathrm{q}=$ quartet, quint = quintet, sept $=$ septet, $\mathrm{m}=$ multiplet. High-resolution mass spectroscopy (HMRS) were recorded on a Q-TOF .

\section{General Procedure for the Multicomponent Synthesis of Unsymmetrical}

Imidazolium Salts 3 . The reaction was performed in open vessel under air atmosphere. In a round-bottomed flask were placed 2,6-diisopropylaniline (1 mmol, 1.0 equiv.), alkylamine ( $1 \mathrm{mmol}, 1.0$ equiv.) and acetic acid ( $4.5 \mathrm{mmol}, 4.5$ equiv.), then the mixture was heated at $60{ }^{\circ} \mathrm{C}$ for 5 minutes and $\mathrm{MgSO}_{4}(2 \mathrm{mmol}, 2$ equiv.) was added (mixture A). In another round-bottomed flask were placed glyoxal (1 mmol, 1.0 equiv., $40 \%$ weight in aqueous solution), formaldehyde ( $1 \mathrm{mmol}, 1.0$ equiv., $37 \%$ weight in aqueous solution) and acetic acid ( $4.5 \mathrm{mmol}, 4.5$ equiv.), then the mixture was heated at $60{ }^{\circ} \mathrm{C}$ for 5 minutes and $\mathrm{ZnCl}_{2}(1.2 \mathrm{mmol}, 1.2$ equiv., $1 \mathrm{M}$ in $\mathrm{Et}_{2} \mathrm{O}$ ) was added (mixture $\mathrm{B}$ ). At $60{ }^{\circ} \mathrm{C}$ mixture $\mathrm{B}$ was added to mixture $\mathrm{A}$ and the 
resulting mixture was stirred at $60{ }^{\circ} \mathrm{C}$ for 25 minutes then cooled down to room temperature. An aliquot of the crude reaction mixture was taken and a ${ }^{1} \mathrm{H}$ NMR was recorded to determine the selectivity of the reaction, which was calculated by integration of characteristic signals of the different compounds. Dichloromethane (25 $\mathrm{mL}$ ) and $3 \mathrm{M}$ aqueous solution of $\mathrm{HCl}(50 \mathrm{~mL})$ were added and the resulting mixture was stirred at room temperature for 1 hour. Then the organic layer was separated. Water $(50 \mathrm{~mL})$ and potassium hexafluorophosphate or potassium tetrafluoroborate (1.0 mmol, 1.0 equiv.) was added and the mixture was stirred at room temperature for 1 hour. The organic layer was separated, dried over magnesium sulfate, filtered and the solvents were evaporated under reduced pressure. The desired imidazolium salt was isolated either by flash chromatography on silica gel or recrystallization.

\section{General Procedure for the Multicomponent Synthesis of Unsymmetrical}

Imidazolium Salts 7 . In a round-bottomed flask were placed alkylamine $(0.53 \mathrm{mmol}$, 1 equiv.) and acetic acid ( $1.20 \mathrm{mmol}, 2.25$ equiv.) then the mixture was heated at $40{ }^{\circ} \mathrm{C}$ for $5 \mathrm{~min}$ (mixture A). In another round-bottomed flask were placed glyoxal ( $0.26 \mathrm{mmol}, 0.5$ equiv., $40 \% \mathrm{wt}$ in aqueous solution), formaldehyde ( $0.026 \mathrm{mmol}, 0.5$ equiv., $37 \%$ wt in aqueous solution) and acetic acid acid (1.20 mmol, 2.25 equiv.) then the mixture was heated at $40{ }^{\circ} \mathrm{C}$ for 5 min (mixture $\mathrm{B}$ ). At $40{ }^{\circ} \mathrm{C}$ mixture $\mathrm{B}$ was added to mixture $A$ and the resulting mixture was stirred at $40{ }^{\circ} \mathrm{C}$ for $25 \mathrm{~min}$ then cooled down to room temperature. Dichloromethane $(25 \mathrm{~mL})$ was added and the organic layer was washed with brine $(3 \times 10 \mathrm{~mL})$. The organic layer was separated, then water $(5 \mathrm{~mL})$ and potassium hexafluorophosphate $(48 \mathrm{mg}, 0.26 \mathrm{mmol})$ were added and the mixture was stirred at room temperature for 1 hour. The organic layer was separated, dried over magnesium sulfate, filtered and the solvents were 
evaporated under reduced pressure. The desired imidazolium salt 7 was isolated without further purification.

\section{General Procedure for the Synthesis of Copper Complexes 3.CuCl.} Hexafluorophosphate salt $3(0.24 \mathrm{mmol}, 1$ equiv.) was loaded on an anion exchange resin Dowex® $1 \times 2$ chloride form $(2.4 \mathrm{ml}$ of resin for $0.24 \mathrm{mmol}$ of hexafluorophosphate salt) with milli-Q water / acetone (1/1) as an eluent. After removal of solvents under reduced pressure, the residue was dissolved in dichloromethane, dried over $\mathrm{MgSO}_{4}$, filtered and concentrated under reduced pressure to give the corresponding chloride salt. In a dry Schlenk, under argon atmosphere, were placed $\mathrm{Ag}_{2} \mathrm{O}$ ( $0.24 \mathrm{mmol}$, 1 equiv.), chloride imidazolium salt $(0.24$ mmol, 1 equiv.), dichloromethane $(25 \mathrm{~mL})$ and $4 \AA$ molecular sieves. The mixture was stirred at room temperature overnight in darkness (alumina foil) then $\mathrm{CuCl}(0.24$ mmol, 1 equiv.) was added and the resulting mixture was stirred at room temperature for $4 \mathrm{~h}$ in darkness. The mixture was then filtered on a celite bed with dichloromethane and the solvent was removed under reduced pressure. The crude solid was precipitated in dichloromethane/pentane (1/5) to afford the desired copper complex 3.CuCl.

General Procedure for Copper-Catalyzed Asymmetric Borylation. Starting from the imidazolium salts ( $3 \boldsymbol{h}$ and $\mathbf{7 h})$ : In the glove box, $\mathrm{Cu}(\mathrm{OTf})_{2}(4 \mathrm{~mol} \%)$, ligand (12 mol\%), NaOtBu (20 mol\%) and THF (1 mL) were added in a flame-dried microwave flask. The resulting mixture was stirred at room temperature for 10 minutes and bis(pinacolato)diboron ( $0.55 \mathrm{mmol}, 1.1$ equiv.) was added. The mixture was stirred for an extra 10 minutes and the solution was cooled down to $-50{ }^{\circ} \mathrm{C}$. Then, a solution containing $\mathrm{MeOH}(1.0 \mathrm{mmol}, 2$ equiv. $)$, ethyl cinnamate $(0.5 \mathrm{mmol}, 1$ equiv.) and THF (1 mL) was slowly added and the mixture was stirred 3 hours at - 
$50{ }^{\circ} \mathrm{C}$. Then, the oxidation step was carried out with the successive addition of $\mathrm{NaBO}_{3} .4 \mathrm{H}_{2} \mathrm{O}$ (2.5 mmol, 5 equiv.) and water $(2 \mathrm{~mL})$, after which the mixture was stirred at room temperature for 3 hours. Water $(10 \mathrm{~mL})$ was added and the aqueous layer was extracted with ethyl acetate $(3 \times 20 \mathrm{~mL})$. The organics layers were combined, washed with brine $(20 \mathrm{~mL})$, dried over $\mathrm{MgSO}_{4}$, filtered and concentrated under reduced pressure. The crude product was purified by silica gel chromatography (pentane/diethyl ether, 8/2) to give the corresponding product 9 as a colorless oil.

Starting from the isolated copper complex (3h.CuCl): In the glove box, $3 \mathbf{h} . \mathbf{C u C l}(4$ $\mathrm{mol} \%), \mathrm{Cs}_{2} \mathrm{CO}_{3}(8 \mathrm{~mol} \%)$, bis(pinacolato)diboron (0.55 mmol, 1.1 equiv.) and THF (1 $\mathrm{mL}$ ) were added in a microwave flask. The resulting mixture was stirred at room temperature for 10 minutes and the solution was cooled down to $-50{ }^{\circ} \mathrm{C}$. Then, a solution containing $\mathrm{MeOH}(1.0 \mathrm{mmol}, 2$ equiv. $)$, ethyl cinnamate ( $0.5 \mathrm{mmol}, 1$ equiv.) and THF $(1 \mathrm{~mL})$ was slowly added at $-50^{\circ} \mathrm{C}$ and the mixture was stirred 3 hours at $50{ }^{\circ} \mathrm{C}$. Then, the oxidation step was carried out with the successive addition of $\mathrm{NaBO}_{3} .4 \mathrm{H}_{2} \mathrm{O}(1 \mathrm{mmol}, 5$ equiv. $)$ and water $(1 \mathrm{~mL})$, after which the mixture was stirred at room temperature for 3 hours. Water $(5 \mathrm{~mL})$ was added and the aqueous layer was extracted with ethyl acetate $(3 \times 10 \mathrm{~mL})$. The organics layers were combined, washed with brine $(10 \mathrm{~mL})$, dried over $\mathrm{MgSO}_{4}$, filtered and concentrated under reduced pressure. The crude product was purified by silica gel chromatography (pentane /diethyl ether: 8/2) to give the corresponding product 9 as a colorless oil.

\section{General Procedure for Copper-Catalyzed Asymmetric Allylic Alkylation.}

A flame-dried Schlenk tube, under an argon atmosphere, was charged with $\left[\mathrm{Cu}(\mathrm{OTf})_{2}\right] \cdot \mathrm{C}_{6} \mathrm{H}_{6}(0.5 \mathrm{~mol} \%)$ and $\mathbf{3 k}(1 \mathrm{~mol} \%)$. Freshly distillated ethyl acetate $(0.25$ $\mathrm{mL}$ ) was then added and the reaction mixture was stirred 10 minutes at room 
temperature followed by the addition of n-BuLi (1.6M in hexanes, $2.5 \mathrm{~mol} \%)$. The reaction was stirred 10 minutes at room temperature and $\mathrm{Et}_{2} \mathrm{Zn}$ (1.5 mmol, 3 equiv.) was added. After cooling the reaction vessel to $0{ }^{\circ} \mathrm{C}$, the phosphate $(0.5 \mathrm{mmol}, 1$ equiv.) was added. As soon as the addition of the substrate was completed, the ice bath was removed. The reaction mixture was stirred at room temperature until total consumption of the phosphate. Upon completion of the reaction, a $1 \mathrm{M}$ aqueous solution of $\mathrm{HCl}$ was added and the compound was extracted with diethyl ether. The combined organic layers were then washed with a saturated aqueous solution of $\mathrm{NaHCO}_{3}$, brine and dried over $\mathrm{MgSO}_{4}$. The solvents were carefully removed under vacuum. The crude product was purified by silica gel chromatography (pentane) to isolate the corresponding product 11 as a colorless oil.

Characterization Data of Isolated Compounds. 3-cyclododecyl-1-(2,6diisopropylphenyl)imidazolium hexafluorophosphate (3a): Selectivity $3 a-O A c / b \mathbf{s}_{\mathrm{C}_{12}}{ }^{-}$ OAc/IPr-OAc $=>95 /$ traces/traces. Purification over silica gel (dichloromethane then dichloromethane/ethyl acetate: 9/1). Pale brown solid (481 mg, 89\%). m. p.: $173{ }^{\circ} \mathrm{C}$. ${ }^{1} \mathrm{H}$ NMR (400 MHz, Chloroform-d) $\delta 8.61$ (dd, $\left.J=1.7,1.7 \mathrm{~Hz}, 1 \mathrm{H}\right), 7.66(\mathrm{dd}, J=1.8$, $1.8 \mathrm{~Hz}, 1 \mathrm{H}), 7.49(\mathrm{t}, J=7.8 \mathrm{~Hz}, 1 \mathrm{H}), 7.33-7.17(\mathrm{~m}, 3 \mathrm{H}), 4.73-4.67(\mathrm{~m}, 1 \mathrm{H}), 2.21-2.06$ (m, 4H), 1.95-1.70 (m, 2H), 1.61-1.18 (m, 18H), $1.13(\mathrm{~d}, J=7.6 \mathrm{~Hz}, 6 \mathrm{H}), 1,11(\mathrm{~d}, J=$

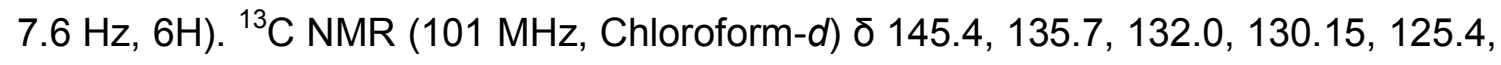
$124.7,121.7,59.7,30.2,28.9,24.3,24.0,23.8,23.5,23.3,23.3,21.3 .{ }^{19} \mathrm{~F}$ NMR $(376$ MHz, Chloroform-d) $\delta-72.16(\mathrm{~d}, J=713 \mathrm{~Hz}) .{ }^{31} \mathrm{P}$ NMR $(162 \mathrm{MHz}$, Chloroform- $d) \delta-$ 144.32 (sept, $J=713 \mathrm{~Hz}$ ). HRMS (ESI) calcd. for $\mathrm{C}_{27} \mathrm{H}_{43} \mathrm{~N}_{2}{ }^{+}\left(M-P F_{6}\right): m / z ~ 395.34207$, found: 395.3422 (0 ppm). Anal. Calcd. for $\mathrm{C}_{27} \mathrm{H}_{43} \mathrm{~F}_{6} \mathrm{~N}_{2} \mathrm{P}: \mathrm{C}, 59.99 \% ; \mathrm{H}, 8.02 \%$; , 5.18\%; found: C, 59.85\%; H, 7.77\%; N, 4.99\% 
Selectivity 3b-OAc/bis ${ }_{\mathrm{C} 8}-\mathrm{OAc} / \mathrm{IPr}-\mathrm{OAc}=91 / 9 / 0$. Purification over silica gel (dichloromethane) followed by recrystallization in dichloromethane/cyclohexane. White solid (339 mg, 70\%). m. p.: $196{ }^{\circ} \mathrm{C} .{ }^{1} \mathrm{H}$ NMR (400 MHz, Chloroform-d) $\delta 8.63$ $(\mathrm{dd}, J=1.7,1.7 \mathrm{~Hz}, 1 \mathrm{H}), 7.67(\mathrm{dd}, J=1.9,1.9 \mathrm{~Hz}, 1 \mathrm{H}), 7.52(\mathrm{t}, J=7.8 \mathrm{~Hz}, 1 \mathrm{H}), 7.30$ (s, 1H), $7.28(\mathrm{~s}, 1 \mathrm{H}), 7.25(\mathrm{dd}, J=1.5,1.5 \mathrm{~Hz}, 1 \mathrm{H}), 4.82$ (quint., $J=7.3 \mathrm{~Hz}, 1 \mathrm{H}$ ), 2.28-2.01 (m, 6H), 1.91-1.52 (m, 10H), $1.17(\mathrm{~d}, J=6.8 \mathrm{~Hz}, 6 \mathrm{H}), 1.14(\mathrm{~d}, J=6.8 \mathrm{~Hz}$, 6H). ${ }^{13} \mathrm{C}$ NMR (101 MHz, Chloroform-d) $\delta 145.5,135.3,132.0,130.2,125.3,124.7$, $121.3,62.4,33.9,28.9,26.4,25.4,24.4,24.0,23.8 .{ }^{19} \mathrm{~F}$ NMR (376 MHz, Chloroformd) $\delta-72.20(\mathrm{~d}, J=713 \mathrm{~Hz}) .{ }^{31} \mathrm{P}$ NMR $(162 \mathrm{MHz}$, Chloroform-d) $\delta-144.29$ (sept, $J=$ $713 \mathrm{~Hz}$ ). HRMS (ESI) calcd. for $\mathrm{C}_{23} \mathrm{H}_{35} \mathrm{~N}_{2}{ }^{+}\left(M-P F_{6}\right): \mathrm{m} / \mathrm{z} 339.27947$, found: 339.2798 (1 ppm). Anal. Calcd. for $\mathrm{C}_{23} \mathrm{H}_{35} \mathrm{~F}_{6} \mathrm{~N}_{2} \mathrm{P}: \mathrm{C}, 57.02 \% ; \mathrm{H}, 7.28 \% ; \mathrm{N}, 5.78 \%$; found: $\mathrm{C}$, $57.05 \% ; \mathrm{H}, 6.87 \% ; \mathrm{N}, 5.68 \%$

3-cyclopentyl-1-(2,6-diisopropylphenyl)imidazolium hexafluorophosphate (3c): Selectivity 3c-OAc/bis $\mathrm{C}_{5}-\mathrm{OAc} / \mathrm{IPr}-\mathrm{OAc}=96 / 4 / 0$. Purification over silica gel (dichloromethane). Pale brown solid (345 mg, 78\%). m. p.: $172{ }^{\circ} \mathrm{C} .{ }^{1} \mathrm{H}$ NMR (400 $\mathrm{MHz}$, Chloroform-d) $\delta 8.55(\mathrm{dd}, J=1.7,1.7 \mathrm{~Hz}, 1 \mathrm{H}), 7.68(\mathrm{dd}, J=1.9,1.9 \mathrm{~Hz}, 1 \mathrm{H})$, $7.51(\mathrm{t}, J=7.8 \mathrm{~Hz}, 1 \mathrm{H}), 7.32-7.24(\mathrm{~m}, 3 \mathrm{H}), 4.98$ (quint, $J=7.1 \mathrm{~Hz}, 1 \mathrm{H}$ ), 2.55-2.32 (m, 2H), 2.21 (sept, $J=6.7 \mathrm{~Hz}, 2 \mathrm{H}), 2.09-1.67(\mathrm{~m}, 6 \mathrm{H}), 1.15(\mathrm{~d}, J=6.8 \mathrm{~Hz}, 6 \mathrm{H}), 1.12$ $(\mathrm{d}, J=6.8 \mathrm{~Hz}, 6 \mathrm{H}) .{ }^{13} \mathrm{C}$ NMR $(101 \mathrm{MHz}$, Chloroform- $d) \delta 145.4,135.5,132.0,130.1$, $125.5,124.7,121.5,62.1,33.5,28.8,24.3,23.9,23.8 .{ }^{19} \mathrm{~F}$ NMR $(376 \mathrm{MHz}$, Chloroform-d) $\delta-72.44\left(\mathrm{~d}, J=713 \mathrm{~Hz}\right.$ ). ${ }^{31} \mathrm{P}$ NMR (162 MHz, Chloroform- $d$ ) $\delta-144.37$ (sept, $J=713 \mathrm{~Hz}$ ). HRMS (ESI) calcd. for $\mathrm{C}_{20} \mathrm{H}_{29} \mathrm{~N}_{2}{ }^{+}\left(\mathrm{M}-\mathrm{PF}_{6}\right): \mathrm{m} / \mathrm{z} 297.23307$, found: 
297.2331 (0 ppm). Anal. Calcd. for $\mathrm{C}_{20} \mathrm{H}_{29} \mathrm{~F}_{6} \mathrm{~N}_{2} \mathrm{P}: \mathrm{C}, 54.30 \% ; \mathrm{H}, 6.61 \% ; \mathrm{N}, 6.33 \%$; found: C, $54.72 \% ; \mathrm{H}, 6.77 \% ; \mathrm{N}, 6.39 \%$

3-cyclobutyl-1-(2,6-diisopropylphenyl)imidazolium hexafluorophosphate (3d): Selectivity $3 d-O A c / b i s_{C 4}-O A c / / P r-O A c=86 / 14 / 0$. Purification over silica gel (dichloromethane/pentane: 8/2 then dichloromethane). Pale brown solid (283 mg, $66 \%$ ). Single-crystals of $\mathbf{3 d}$ were obtained by slow evaporation of a saturated solution in dichoromethane/pentane. m. p.: $161{ }^{\circ} \mathrm{C} .{ }^{1} \mathrm{H}$ NMR $(400 \mathrm{MHz}$, Chloroform-d) $\delta 8.55$ (dd, $J=1.7,1.7 \mathrm{~Hz}, 1 \mathrm{H}), 7.78(\mathrm{dd}, J=1.8,1.8 \mathrm{~Hz}, 1 \mathrm{H}), 7.52(\mathrm{t}, J=7.8 \mathrm{~Hz}$, 1H), $7.30(\mathrm{~s}, 1 \mathrm{H}), 7.28(\mathrm{~s}, 1 \mathrm{H}), 7.27-7.24(\mathrm{~m}, 1 \mathrm{H}), 5.13$ (quint, $J=8.5 \mathrm{~Hz}, 1 \mathrm{H}), 2.74-$ $2.62(\mathrm{~m}, 2 \mathrm{H}), 2.58-2.44(\mathrm{~m}, 2 \mathrm{H}), 2.22(\mathrm{sept}, J=6.8 \mathrm{~Hz}, 2 \mathrm{H}), 2.06-1.88(\mathrm{~m}, 2 \mathrm{H}), 1.16$ $(\mathrm{d}, J=6.8 \mathrm{~Hz}, 6 \mathrm{H}), 1.12(\mathrm{~d}, J=6.8 \mathrm{~Hz}, 6 \mathrm{H}) \cdot{ }^{13} \mathrm{C}$ NMR $(101 \mathrm{MHz}$, Chloroform- $d) \delta$ $145.5,135.1,132.0,130.1,125.4,124.7,121.4,54.0,30.7,28.7,24.4,23.9,14.6 .{ }^{19} \mathrm{~F}$ NMR (376 MHz, Chloroform- $d$ ) $\delta-72.47$ (d, $J=713 \mathrm{~Hz}) .{ }^{31} \mathrm{P}$ NMR $(162 \mathrm{MHz}$, Chloroform-d) $\delta-144.35$ (sept, $J=713 \mathrm{~Hz}$ ). HRMS (ESI) calcd. for $\mathrm{C}_{19} \mathrm{H}_{27} \mathrm{~N}_{2}{ }^{+}(\mathrm{M}-$ $\mathrm{PF}_{6}$ ): $\mathrm{m} / \mathrm{z} 283.21687$, found: 283.2169 (0 ppm). Anal. Calcd. for $\mathrm{C}_{19} \mathrm{H}_{27} \mathrm{~F}_{6} \mathrm{~N}_{2} \mathrm{P}: \mathrm{C}$, $53.27 \%$; $\mathrm{H}, 6.35 \%$; N, 6.54\%; found: C, 53.75\%; $\mathrm{H}, 6.38 \%$; N, $6.29 \%$

3-adamantyl-1-(2,6-diisopropylphenyl)imidazolium tetrafluoroborate $\quad\left(3 e-B_{4}\right)$ : Selectivity 3e-OAc/7e-OAc/IPr-OAc $=94 / 6 / 0$. Purification over silica gel (dichloromethane then dichloromethane/ethyl acetate: 9/1) following by recrystallization in ethyl acetate. White solid $(1.9 \mathrm{~g}, 75 \%$ from $5.6 \mathrm{mmol}$ of corresponding alkylamine). m. p.: $218^{\circ} \mathrm{C} .{ }^{1} \mathrm{H}$ NMR $(400 \mathrm{MHz}$, Chloroform-d) $\delta 8.83$ (dd, $J=1.7,1.7 \mathrm{~Hz}, 1 \mathrm{H}), 7.94(\mathrm{dd}, J=1.9,1.9 \mathrm{~Hz}, 1 \mathrm{H}), 7.51(\mathrm{t}, J=7.8 \mathrm{~Hz}, 1 \mathrm{H}), 7.31$ (dd, $J=1.9,1.9 \mathrm{~Hz}, 1 \mathrm{H}), 7.29(\mathrm{~s}, 1 \mathrm{H}), 7.27$ (s, 1H), 2.36-2.25 (m, 9H), 2.20 (sept, $J=$ 
$6.8 \mathrm{~Hz}, 2 \mathrm{H}), 1.87-1.74(\mathrm{~m}, 6 \mathrm{H}), 1.18(\mathrm{~d}, J=6.8 \mathrm{~Hz}, 6 \mathrm{H}), 1.14(\mathrm{~d}, J=6.8 \mathrm{~Hz}, 6 \mathrm{H}) .{ }^{13} \mathrm{C}$

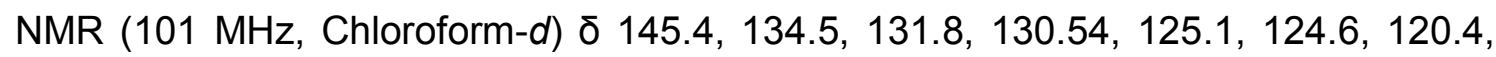
61.6, 42.6, 35.2, 29.6, 28.8, 24.3, 24.0. ${ }^{19} \mathrm{~F}$ NMR (376 MHz, Chloroform-d) $\delta-151.57$. ${ }^{11} \mathrm{~B}$ NMR (128 MHz, Chloroform-d) $\delta$-1.02. HRMS (ESI) calcd. for $\mathrm{C}_{25} \mathrm{H}_{35} \mathrm{~N}_{2}{ }^{+}$(M$\left.\mathrm{BF}_{4}\right): \mathrm{m} / \mathrm{z} 363.28002$, found: 363.2799 (0 ppm)

3-cyclopropyl-1-(2,6-diisopropylphenyl)imidazolium hexafluorophosphate (3f):

Selectivity 3f-OAc/bis $\mathrm{c}_{3}-\mathrm{OAc} / \mathrm{IPr}-\mathrm{OAc}=70 / 26 / 4$. Purification over silica gel (dichloromethane/pentane: 8/2 then dichloromethane). Pale brown solid (174 mg, 42\%). m. p.: $69^{\circ} \mathrm{C} .{ }^{1} \mathrm{H}$ NMR (400 MHz, Chloroform-d) $\delta 8.62$ (dd, J = 1.6, $1.6 \mathrm{~Hz}$, 1H), $7.63(\mathrm{dd}, J=1.9,1.9 \mathrm{~Hz}, 1 \mathrm{H}), 7.53(\mathrm{t}, J=7.9 \mathrm{~Hz}, 1 \mathrm{H}), 7.31(\mathrm{~s}, 1 \mathrm{H}), 7.29(\mathrm{~s}, 1 \mathrm{H})$, $7.21(\mathrm{dd}, J=1.9,1.8 \mathrm{~Hz}, 1 \mathrm{H}), 4.02-3.94(\mathrm{~m}, 1 \mathrm{H}), 2.23$ (sept, $J=6.8 \mathrm{~Hz}, 2 \mathrm{H}), 1.33-$ $1.22(\mathrm{~m}, 4 \mathrm{H}), 1.17(\mathrm{~d}, J=6.8 \mathrm{~Hz}, 6 \mathrm{H}), 1.13(\mathrm{~d}, J=6.8 \mathrm{~Hz}, 6 \mathrm{H}) .{ }^{13} \mathrm{C} \mathrm{NMR}(101 \mathrm{MHz}$, Chloroform-d) $\delta 145.5,137.2,132.1,130.0,125.0,124.7,123.7,32.1,28.7,24.4$, 23.9, 7.4. ${ }^{19} \mathrm{~F}$ NMR (376 MHz, Chloroform-d) $\delta-72.58(\mathrm{~d}, J=714 \mathrm{~Hz}) .{ }^{31} \mathrm{P}$ NMR (162 MHz, Chloroform-d) $\delta-144.42$ (sept, $J=713 \mathrm{~Hz}$ ). HRMS (ESI) calcd. for $\mathrm{C}_{18} \mathrm{H}_{25} \mathrm{~N}_{2}{ }^{+}$ $\left(\mathrm{M}^{-P F_{6}}\right): \mathrm{m} / \mathrm{z} 269.20177$, found: 269.2018 (0 ppm)

(S)-1-(2,6-diisopropylphenyl)-3-(1-phenylethyl)imidazolium hexafluorophosphate (3g):

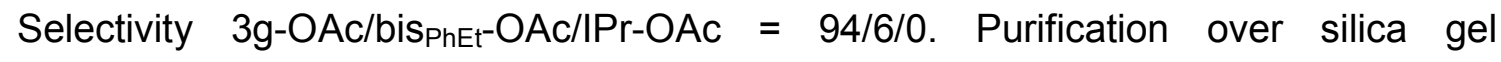
(dichloromethane). Pale brown solid (341 mg, 71\%). m. p.: $178{ }^{\circ} \mathrm{C} .[a]_{D}^{20}:-25.4$ (c = 1, chloroform). ${ }^{1} \mathrm{H}$ NMR (400 MHz, Chloroform-d) $\delta 8.53$ (dd, $J=1.7,1.7 \mathrm{~Hz}, 1 \mathrm{H}$ ), $7.66\left(\mathrm{dd}, J_{1}=1.9,1.9 \mathrm{~Hz}, 1 \mathrm{H}\right), 7.51(\mathrm{t}, J=7.9 \mathrm{~Hz}, 1 \mathrm{H}), 7.46-7.35(\mathrm{~m}, 5 \mathrm{H}), 7.32-$ $7.23(\mathrm{~m}, 3 \mathrm{H}), 5.98(\mathrm{q}, J=7.0 \mathrm{~Hz}, 1 \mathrm{H}), 2.26$ (sept, $J=6.8 \mathrm{~Hz}, 1 \mathrm{H}), 2.11$ (sept, $J=6.8$ $\mathrm{Hz}, 1 \mathrm{H}), 2.02(\mathrm{~d}, J=7.0 \mathrm{~Hz}, 3 \mathrm{H}), 1.15(\mathrm{~d}, J=6.8 \mathrm{~Hz}, 3 \mathrm{H}), 1.13(\mathrm{~d}, J=6.8 \mathrm{~Hz}, 3 \mathrm{H})$, 
$1.11(\mathrm{~d}, J=6.8 \mathrm{~Hz}, 3 \mathrm{H}), 1.06(\mathrm{~d}, J=6.8 \mathrm{~Hz}, 3 \mathrm{H}) .{ }^{13} \mathrm{C}$ NMR $(101 \mathrm{MHz}$, Chloroform- $d$ ) $\delta 145.5,145.3,137.9,132.1,130.1,129.8,126.9,125.2,124.8,124.7,121.8,60.6$, 28.8, 28.8, 24.4, 24.1, 23.9, 20.7. ${ }^{19} \mathrm{~F}$ NMR (376 MHz, Chloroform- $d$ ) $\delta-72.28(\mathrm{~d}, J=$ $713 \mathrm{~Hz}$ ). ${ }^{31} \mathrm{P}$ NMR (162 MHz, Chloroform-d) $\delta-144.27$ (sept, $J=713 \mathrm{~Hz}$ ). HRMS (ESI) calcd. for $\mathrm{C}_{23} \mathrm{H}_{29} \mathrm{~N}_{2}{ }^{+}\left(\mathrm{M}-\mathrm{PF}_{6}\right): \mathrm{m} / \mathrm{z} 333.23252$, found: 333.2330 (1 ppm)

(R)-1-(2,6-diisopropylphenyl)-3-((1-(naphthalen-1-yl)ethyl)imidazolium hexafluorophosphate (3h): Selectivity 3h-OAc/7h-OAc/IPr-OAc $=83 / 17 / 0$. Purification over silica gel (diethyl ether/dichloromethane: 9/1). Pale brown solid (346 mg, 65\%). Single-crystals of $\mathbf{3 h}$ were obtained by slow evaporation of a saturated solution in dichloromethane/pentane. m. p.: $214^{\circ} \mathrm{C} .[a]_{D}^{20}:-36.2\left(\mathrm{c}=1\right.$, chloroform). ${ }^{1} \mathrm{H}$ NMR (400 MHz, Chloroform-d) $\delta 8.43(\mathrm{dd}, J=1.7,1.7 \mathrm{~Hz}, 1 \mathrm{H}), 7.94-7.87(\mathrm{~m}, 3 \mathrm{H}), 7.74-$ $7.71(\mathrm{~m}, 1 \mathrm{H}), 7.63(\mathrm{dd}, J=1.9,1.9 \mathrm{~Hz}, 1 \mathrm{H}), 7.58-7.49(\mathrm{~m}, 3 \mathrm{H}), 7.45(\mathrm{t}, J=7.8 \mathrm{~Hz}$, 1H), 7.23-7.19 (m, 3H), $6.71(\mathrm{q}, J=6.8 \mathrm{~Hz}, 1 \mathrm{H}), 2.17(\mathrm{~d}, J=6.9 \mathrm{~Hz}, 3 \mathrm{H}), 2.14-2.03$ (m, 2H), $1.07(\mathrm{~d}, J=6.8 \mathrm{~Hz}, 3 \mathrm{H}), 1.04(\mathrm{~d}, J=6.8 \mathrm{~Hz}, 3 \mathrm{H}), 1.03(\mathrm{~d}, J=6.8 \mathrm{~Hz}, 3 \mathrm{H})$, $0.91(\mathrm{~d}, J=6.8 \mathrm{~Hz}, 3 \mathrm{H}) .{ }^{13} \mathrm{C}$ NMR $(101 \mathrm{MHz}$, Chloroform-d) $\delta 145.4,145.2,135.7$, $134.2,132.1,131.9,131.0,130.4,129.9,129.6,127.8,126.6,125.6,125.2,125.2$ $124.7,124.7,122.3,121.8,57.0,28.7,28.7,24.1,24.1,24.1,23.8,20.8 .{ }^{19} \mathrm{~F}$ NMR (376 MHz, Chloroform- $d$ ) $\delta-72.11(\mathrm{~d}, J=713 \mathrm{~Hz}) .{ }^{31} \mathrm{P}$ NMR $(162 \mathrm{MHz}$, Chloroform- $d$ ) $\delta-144.16$ (sept, $J=713 \mathrm{~Hz}$ ). HRMS (ESI) calcd. for $\mathrm{C}_{27} \mathrm{H}_{31} \mathrm{~N}_{2}{ }^{+}\left(\mathrm{M}-\mathrm{PF}_{6}\right): \mathrm{m} / \mathrm{z}$ 383.24817, found: 383.2485 (1 ppm). Anal. Calcd. for $\mathrm{C}_{27} \mathrm{H}_{31} \mathrm{~F}_{6} \mathrm{~N}_{2} \mathrm{P}: \mathrm{C}, 61.36 \% ; \mathrm{H}$, 5.91\%; N, 5.30\%; found: C, $61.74 \% ; H, 5.91 \% ; ~ N, 5.24 \%$

(R)-3-(2,3-dihydro-inden-1-yl)-1-(2,6-diisopropylphenyl)imidazolium

hexafluorophosphate (3i): Selectivity 3i-OAc/bis Ind $_{-} \mathrm{OAc} / \mathrm{IPr}-\mathrm{OAc}=93 / 7 / 0$. Purification 
over silica gel (dichloromethane) followed by recrystallization in dichloromethane/cyclohexane. White solid (320 mg, 65\%). Single-crystals of $3 \mathbf{i}$ were obtained by slow evaporation of a saturated solution in dichloromethane/pentane. $\mathrm{m}$. p.: $205^{\circ} \mathrm{C} .[a]_{D}^{20}:+13.3$ (c = 1, chloroform). ${ }^{1} \mathrm{H}$ NMR $(400 \mathrm{MHz}$, Chloroform-d $) \delta 8.54$ (dd, $J=1.7,1.7 \mathrm{~Hz}, 1 \mathrm{H}), 7.53(\mathrm{t}, J=7.8 \mathrm{~Hz}, 1 \mathrm{H}), 7.45-7.35(\mathrm{~m}, 3 \mathrm{H}), 7.32-7.23(\mathrm{~m}$, $5 \mathrm{H}), 6.29(\mathrm{dd}, J=7.8,4.2 \mathrm{~Hz}, 1 \mathrm{H}), 3.27-2.90(\mathrm{~m}, 3 \mathrm{H}), 2.41-2.17(\mathrm{~m}, 3 \mathrm{H}), 1.18(\mathrm{~d}, J$ $=6.8 \mathrm{~Hz}, 3 \mathrm{H}), 1.16(\mathrm{~d}, J=6.8 \mathrm{~Hz}, 3 \mathrm{H}), 1.15(\mathrm{~d}, J=6.8 \mathrm{~Hz}, 6 \mathrm{H}) .{ }^{13} \mathrm{C} N M R(101 \mathrm{MHz}$, Chloroform-d) $\delta 145.6,145.3,144.5,137.8,135.7,132.2,130.6,130.0,128.2,125.9$, $125.6,125.0,124.9,124.8,121.7,66.0,34.5,30.4,28.9,28.8,24.3,24.1 .{ }^{19} \mathrm{~F}$ NMR (376 MHz, Chloroform-d) $\delta-72.30(\mathrm{~d}, J=713 \mathrm{~Hz}) .{ }^{31} \mathrm{P}$ NMR $(162 \mathrm{MHz}$, Chloroform-d) $\delta-144.27$ (sept, $J=713 \mathrm{~Hz}$ ). HRMS (ESI) calcd. for $\mathrm{C}_{24} \mathrm{H}_{29} \mathrm{~N}_{2}{ }^{+}\left(M-P F_{6}\right): \mathrm{m} / \mathrm{z}$ 345.23252, found: 345.2327 (0 ppm). Anal. Calcd. for $\mathrm{C}_{24} \mathrm{H}_{29} \mathrm{~F}_{6} \mathrm{~N}_{2} \mathrm{P}: \mathrm{C}, 58.77 \%$; $\mathrm{H}$, $5.96 \% ; \mathrm{N}, 5.71 \%$; found: C, 58.64\%; H, 6.24\%; N, 5.50\%

\section{(1R,2R,3R, 5S)-1-(2,6-diisopropylphenyl)-3-(isopinocampheyl)imidazolium}

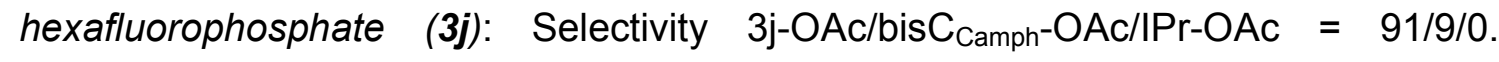
Purification over silica gel (diethyl ether/dichloromethane: 9/1). White solid (260 mg, 51\%). m. p.: $177^{\circ} \mathrm{C} .[a]_{D}^{20}:-3.5$ (c = 1, chloroform). ${ }^{1} \mathrm{H}$ NMR (400 MHz, Chloroformd) $\delta 8.78(\mathrm{dd}, J=1.7,1.7 \mathrm{~Hz}, 1 \mathrm{H}), 7.74(\mathrm{dd}, J=1.9,1.9 \mathrm{~Hz}, 1 \mathrm{H}), 7.52(\mathrm{t}, J=7.8 \mathrm{~Hz}$, 1H), $7.35\left(\mathrm{dd}, J_{1}=1.9,1.9 \mathrm{~Hz}, 1 \mathrm{H}\right), 7.34-7.24(\mathrm{~m}, 2 \mathrm{H}), 5.08(\mathrm{dt}, J=10.2,7.2 \mathrm{~Hz}$, 1H), 2.97-2.85 (m, 1H), 2.68-2.57 (m, 1H), 2.39-2.20 (m, 2H), 2.19-2.01 (m, 3H), 2.03-1.94 (m, 2H), $1.29(\mathrm{~s}, 3 \mathrm{H}), 1.20-1.11(\mathrm{~m}, 15 \mathrm{H}), 1.09(\mathrm{~s}, 3 \mathrm{H}) .{ }^{13} \mathrm{C}$ NMR (101 $\left.\mathrm{MHz}, \mathrm{CDCl}_{3}\right) \delta 145.7,145.3,136.9,132.1,130.0,126.3,124.9,124.6,120.6,60.8$, $47.4,45.8,41.4,39.1,36.2,35.4,29.0,28.9,28.1,24.5,24.4,24.0,23.7,23.1,19.7$. ${ }^{19} \mathrm{~F}$ NMR (376 MHz, Chloroform-d) $\delta-72.05(\mathrm{~d}, J=713 \mathrm{~Hz}) \cdot{ }^{31} \mathrm{P}$ NMR $(162 \mathrm{MHz}$, 
Chloroform-d) $\delta-144.28$ (sept, $J=714 \mathrm{~Hz}$ ). HRMS (ESI) calcd. for $\mathrm{C}_{25} \mathrm{H}_{37} \mathrm{~N}_{2}{ }^{+}$(M$\mathrm{PF}_{6}$ ): $\mathrm{m} / \mathrm{z}$ 365.29512, found: 365.2953 (0 ppm). Anal. Calcd. for $\mathrm{C}_{25} \mathrm{H}_{37} \mathrm{~F}_{6} \mathrm{~N}_{2} \mathrm{P}: \mathrm{C}$, $58.81 \%$; H, 7.31\%; N, 5.49\%; found: C, 58.94\%; H, 7.57\%; N, 5.79\%

\section{(S)-1-(2,6-diisopropylphenyl)-3-(1-hydroxy-4-methylpentan-2-yl)-imidazolium}

hexafluorophosphate (3k): Selectivity 3k-OAc/bis LeuOH$_{-} \mathrm{OAc} / \mathrm{IPr}-\mathrm{OAc}=$ 91/4.5/4.5. Purification over silica gel (dichloromethane/acetone: 9/1). Brown glassy solid (309 mg, 65\%). $[a]_{D}^{20}:-4.8$ (c = 1, chloroform). ${ }^{1} \mathrm{H}$ NMR (400 MHz, Chloroform-d) $\delta 8.52$ $(\mathrm{dd}, J=1.8,1.8 \mathrm{~Hz}, 1 \mathrm{H}), 7.73(\mathrm{dd}, J=1.8,1.8 \mathrm{~Hz}, 1 \mathrm{H}), 7.53(\mathrm{t}, J=7.8 \mathrm{~Hz}, 1 \mathrm{H}), 7.36-$ $7.24(\mathrm{~m}, 3 \mathrm{H}), 4.77-4.65(\mathrm{~m}, 1 \mathrm{H}), 3.95(\mathrm{dd}, J=12.2,3.4 \mathrm{~Hz}, 1 \mathrm{H}), 3.71(\mathrm{dd}, J=12.2$, $7.6 \mathrm{~Hz}, 1 \mathrm{H}), 2.90$ (br. s, $1 \mathrm{H}), 2.34-2.16(\mathrm{~m}, 2 \mathrm{H}), 1.96-1.89(\mathrm{~m}, 1 \mathrm{H}), 1.76-1.64(\mathrm{~m}$, 1H), $1.52-1.36(\mathrm{~m}, 1 \mathrm{H}), 1.16(\mathrm{~d}, J=6.8 \mathrm{~Hz}, 3 \mathrm{H}), 1.14(\mathrm{~d}, J=6.9 \mathrm{~Hz}, 3 \mathrm{H}), 1.12(\mathrm{~d}, J=$ $6.7 \mathrm{~Hz}, 6 \mathrm{H}), 0.94(\mathrm{~d}, J=6.5 \mathrm{~Hz}, 3 \mathrm{H}), 0.93(\mathrm{~d}, J=6.7 \mathrm{~Hz}, 3 \mathrm{H}) .{ }^{13} \mathrm{C} N M R(101 \mathrm{MHz}$, Chloroform-d) $\delta 145.7,145.3,136.6,132.1,130.0,125.1,124.8,124.6,121.4,64.2$, 62.0, 38.5, 28.8, 28.6, 25.0, 24.2, 24.0, 24.0, 23.9, 22.5, 21.7. ${ }^{31} \mathrm{P}$ NMR (162 MHz, Chloroform-d) $\delta-144.32$ (sept, $J=713 \mathrm{~Hz}$ ). ${ }^{19} \mathrm{~F}$ NMR (376 MHz, Chloroform-d) $\delta-$ $71.83\left(\mathrm{~d}, J=713 \mathrm{~Hz}\right.$ ). HRMS (ESI) calcd. for $\mathrm{C}_{21} \mathrm{H}_{33} \mathrm{~N}_{2} \mathrm{O}^{+}(\mathrm{M}-\mathrm{PF}$ ): $\mathrm{m} / \mathrm{z}$ 329.25929, found: 329.2596 (0 ppm). Anal. Calcd. for $\mathrm{C}_{21} \mathrm{H}_{33} \mathrm{~F}_{6} \mathrm{~N}_{2} \mathrm{OP}: \mathrm{C}, 53.16 \% ; \mathrm{H}, 7.01 \%$; $\mathrm{N}$, 5.90\%; found: C, $53.40 \% ; \mathrm{H}, 7.11 \%$; N, $5.98 \%$

\section{(S)-1-(2,6-diisopropylphenyl)-3-(1-hydroxy-4-methylpentan-2-yl)-imidazolium}

hexafluorophosphate (3I): Selectivity 3I-OAc/bis $\mathrm{ValOH}_{-} \mathrm{OAc} / \mathrm{IPr}-\mathrm{OAc}=$ 92/4/4. Purification over silica gel (dichloromethane/acetone: 95/5) then washing with $\mathrm{Et}_{2} \mathrm{O}$. Brown glassy solid (1.05 g, 46\% from $5.0 \mathrm{mmol}$ of corresponding alkylamine). $[a]_{D}^{20}$ : -10.2 (c = 0.5, chloroform). ${ }^{1} \mathrm{H}$ NMR $(400 \mathrm{MHz}$, Chloroform-d) $\delta 8.51$ (dd, $J=1.5,1.5$ 
$\mathrm{Hz}, 1 \mathrm{H}), 7.75(\mathrm{dd}, J=1.8,1.8 \mathrm{~Hz}, 1 \mathrm{H}), 7.53(\mathrm{t}, J=7.8 \mathrm{~Hz}, 1 \mathrm{H}), 7.33-7.28(\mathrm{~m}, 3 \mathrm{H})$, $4.31(\mathrm{ddd}, J=10.1,6.9,3.2 \mathrm{~Hz}, 1 \mathrm{H}), 4.06(\mathrm{dd}, J=12.3,3.2 \mathrm{~Hz}, 1 \mathrm{H}), 3.95(\mathrm{dd}, J=$ 12.3, 7.0 Hz, 1H), 2.77 (br. s, 1H), 2.38-2.16 (m, 3H), 1.19-1.11 (m, 12H), 1.09 (d, J $=6.7 \mathrm{~Hz}, 3 \mathrm{H}), 0.85(\mathrm{~d}, J=6.7 \mathrm{~Hz}, 3 \mathrm{H}) .{ }^{13} \mathrm{C}$ NMR $(101 \mathrm{MHz}$, Chloroform- $d) \delta$ 145.7, $145.3,136.6,132.1,130.0,125.0,124.8,124.7,122.1,77.5,69.4,61.7,29.3,28.8$, 28.7, 24.2, 24.1, 23.9, 19.1. ${ }^{31} \mathrm{P}$ NMR (162 MHz, Chloroform-d) $\delta-144.32$ (sept, $J=$ $713 \mathrm{~Hz}) .{ }^{19} \mathrm{~F}$ NMR (376 MHz, Chloroform-d) $\delta-71.90$ (d, $J=713 \mathrm{~Hz}$ ). HRMS (ESI) calcd. for $\mathrm{C}_{20} \mathrm{H}_{31} \mathrm{~N}_{2} \mathrm{O}^{+}$(M-PF $)$: m/z 315.24309, found: 315.2431 (0 ppm)

\section{(S)-3-(1-carboxy-3-methylbutyl)-1-(2,6-diisopropylphenyl)imidazolium}

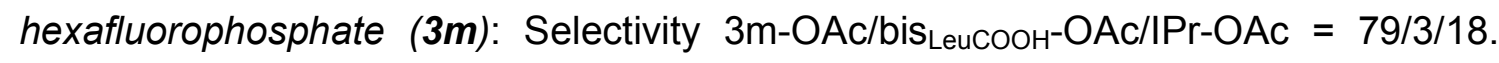

Purification: Chromatography on silica gel (dichloromethane/MeOH: 95/5) and extraction with a saturated aqueous solution of $\mathrm{NaHCO}_{3}$. The aqueous solution was neutralized with $1 \mathrm{M}$ aqueous solution of $\mathrm{HCl}$ and extracted with dichloromethane. Orange glassy solid $(181 \mathrm{mg}, 37 \%) .[a]_{D}^{20}:+31.5\left(\mathrm{c}=1\right.$, chloroform). ${ }^{1} \mathrm{H}$ NMR $(400$ MHz, Chloroform-d) $\delta 9.20(\mathrm{dd}, J=1.5,1.5 \mathrm{~Hz}, 1 \mathrm{H}), 7.95(\mathrm{dd}, J=1.6,1.6 \mathrm{~Hz}, 1 \mathrm{H})$, $7.51(\mathrm{t}, J=7.8 \mathrm{~Hz}, 1 \mathrm{H}), 7.32-7.26(\mathrm{~m}, 2 \mathrm{H}), 7.12(\mathrm{dd}, J=1.9,1.9 \mathrm{~Hz}, 1 \mathrm{H}), 5.19(\mathrm{dd}, J$ $=10.6,4.7 \mathrm{~Hz}, 1 \mathrm{H}), 2.38-2.25(\mathrm{~m}, 2 \mathrm{H}), 2.20(\mathrm{ddd}, J=14.0,9.0,4.7 \mathrm{~Hz}, 1 \mathrm{H}), 1.97$ (ddd, $J=14.9,10.6,5.0 \mathrm{~Hz}, 1 \mathrm{H}), 1.46-1.30(\mathrm{~m}, 1 \mathrm{H}), 1.27-1.06(\mathrm{~m}, 12 \mathrm{H}), 0.98(\mathrm{~d}, J=$ 6.6 Hz, 3H), $0.92(\mathrm{~d}, J=6.6 \mathrm{~Hz}, 3 \mathrm{H}) .{ }^{13} \mathrm{C}$ NMR (101 MHz, chloroform-d) $\delta$ 170.6, $145.8,145.4,137.1,131.8,130.6,124.7,124.6,123.8,123.1,122.8,65.5,43.8$,

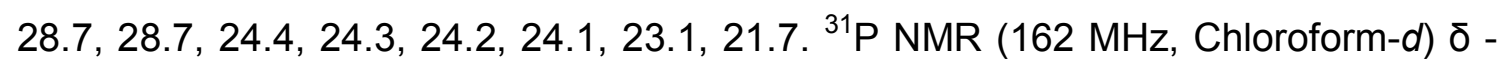
144.33 (sept, $J=713 \mathrm{~Hz}$ ). ${ }^{19} \mathrm{~F}$ NMR (376 MHz, Chloroform-d) $\delta-72.20(\mathrm{~d}, J=713$ $\mathrm{Hz}$ ). HRMS (ESI) calcd. for $\mathrm{C}_{21} \mathrm{H}_{31} \mathrm{~N}_{2} \mathrm{O}_{2}{ }^{+}\left(M-P F_{6}\right): \mathrm{m} / \mathrm{z} 343.238$, found: 343.2376 (1 ppm) 
1,3-bis((R)-1-(naphthalen-1-yl)ethyl)imidazol-3-ium hexafluorophosphate (7h): Yellow powder (492 mg, 97\%). m.p.: $103^{\circ} \mathrm{C} .[a]_{D}^{20}:-118.0$ (c = 0.1, chloroform). ${ }^{1} \mathrm{H}$ NMR (400 MHz, Chloroform-d) $\delta 8.90(\mathrm{dd}, J=1.7,1.7 \mathrm{~Hz}, 1 \mathrm{H}), 8.02-7.68(\mathrm{~m}, 6 \mathrm{H}), 7.58-$ $7.35(\mathrm{~m}, 8 \mathrm{H}), 6.98(\mathrm{~d}, J=1.7 \mathrm{~Hz}, 2 \mathrm{H}), 6.43(\mathrm{q}, J=6.9 \mathrm{~Hz}, 2 \mathrm{H}), 2.06(\mathrm{~d}, J=6.9 \mathrm{~Hz}$, 6H). ${ }^{13} \mathrm{C}$ NMR (101 MHz, Chloroform-d) $\delta 134.5,134.1,132.5,130.6,130.3,129.4$, 127.9, 126.6, 125.5, 124.7, 121.7, 121.3, 56.7, 21.0. ${ }^{31} \mathrm{P}$ NMR (162 MHz, Chloroformd) $\delta-144.03$ (sept, $J=713 \mathrm{~Hz}) .{ }^{19} \mathrm{~F}$ NMR $(376 \mathrm{MHz}$, Chloroform- $d$ ) $\delta-71.78(\mathrm{~d}, J=$ $713 \mathrm{~Hz}$ ). HRMS (ESI) calcd. for $\mathrm{C}_{27} \mathrm{H}_{25} \mathrm{~N}_{2}{ }^{+}\left(\mathrm{M}^{-} \mathrm{PF}_{6}\right): 377.20122 \mathrm{~m} / \mathrm{z}$, found: 377.2013 (0 ppm)

(R)-1-(2,6-diisopropylphenyl)-3-((1-(naphthalen-1-yl)ethyl)imidazol-2-ydene)copper chloride complex (3h.CuCl): White solid (99 mg, 86\%). m.p.: $214^{\circ} \mathrm{C}$. $[a]_{D}^{20}:+85.4$ (c $=1$, chloroform). ${ }^{1} \mathrm{H}$ NMR $(400 \mathrm{MHz}$, Chloroform- $d$ ) $\delta$ 8.13-8.07 (m, 1H), 7.96-7.87 (m, 2H), 7.81-7.73 (m, 1H), 7.63-7.41 (m, 4H), 7.30-7.19 (m, 2H), 6.76-6.71 (m, 2H), $6.68(\mathrm{q}, J=6.9 \mathrm{~Hz}, 1 \mathrm{H}$ ), 2.45 (sept, $J=6.8 \mathrm{~Hz}, 1 \mathrm{H}$ ), 2.27 (sept, $J=6.9 \mathrm{~Hz}, 1 \mathrm{H}$ ), $2.14(\mathrm{~d}, J=6.9 \mathrm{~Hz}, 3 \mathrm{H}), 1.32(\mathrm{~d}, J=6.9 \mathrm{~Hz}, 3 \mathrm{H}), 1.27(\mathrm{~d}, J=6.9 \mathrm{~Hz}, 3 \mathrm{H}), 1.13(\mathrm{~d}, J=$ $6.9 \mathrm{~Hz}, 3 \mathrm{H}), 0.99(\mathrm{~d}, J=6.9 \mathrm{~Hz}, 3 \mathrm{H}) .{ }^{13} \mathrm{C}$ NMR $(101 \mathrm{MHz}$, Chloroform-d) $\delta$ 178.4, $145.8,145.7,134.8,134.2,133.9,131.3,130.5,130.2,129.2,127.0,126.4,125.2$, 124.6, 124.2, 124.2, 123.3, 123.2, 118.5, 56.9, 28.6, 28.4, 25.0, 24.7, 24.3, 24.0, 22.5. HRMS (ESI) calcd. for $\mathrm{C}_{27} \mathrm{H}_{30} \mathrm{~N}_{2}{ }^{35} \mathrm{CINa}^{63} \mathrm{Cu}^{+}(\mathrm{M}+\mathrm{Na}): 503.12857 \mathrm{~m} / \mathrm{z}$, found : 503.1291 (1 ppm)

Ethyl (S)-3-hydroxy-3-phenylpropanoate (9): With 3h: Colorless oil (65 mg, 67\%), e.r $=87: 13 .[a]_{D}^{20}:-35.8\left(\mathrm{c}=1\right.$, chloroform), $\left[\mathrm{Litt}^{19 \mathrm{f}}:[a]_{D}^{20}=-49.2(\mathrm{c}=0.1\right.$, chloroform $)$, 
e.r.= 98:2]. With 7h: Colorless oil (58 mg, 60\%), e.r = $67.5: 32.5$. With 3h.CuCl:

Colorless oil $(74 \mathrm{mg}, 76 \%)$, e.r.= 82 : 18. Enantiomeric excess was measured by chiral HPLC: ${ }^{23}$ OD-H column, Hexane / 2-propanol (90\% / 10\%) - $1 \mathrm{~mL} / \mathrm{min}, \lambda=254$ $\mathrm{nm}, \mathrm{T}=25^{\circ} \mathrm{C}, \mathrm{R}_{\mathrm{t}} 1=7.8 \mathrm{~min}, \mathrm{R}_{\mathrm{t}} 2=10.1 \mathrm{~min} .{ }^{1} \mathrm{H} \mathrm{NMR}(400 \mathrm{MHz}$, Chloroform $-d) \delta$ 7.48-7.12 (m, 5H), $5.14(\mathrm{dt}, J=8.5,3.6 \mathrm{~Hz}, 1 \mathrm{H}), 4.19(\mathrm{q}, J=7.1 \mathrm{~Hz}, 2 \mathrm{H}), 3.26(\mathrm{~d}, J=$ $3.4 \mathrm{~Hz}, 1 \mathrm{H}), 2.88-2.59(\mathrm{~m}, 2 \mathrm{H}), 1.27(\mathrm{t}, J=7.1 \mathrm{~Hz}, 3 \mathrm{H}),{ }^{13} \mathrm{C} N M R(101 \mathrm{MHz}$, Chloroform-d) $\delta 172.6,142.6,128.7,127.9,125.8,70.4,61.0,43.5,14.3$.

(S)-(3-methylpent-1-en-3-yl)benzene (11a): Colorless oil (58 mg, 73\%, conversion $>95 \%) . \mathrm{S}_{\mathrm{N}} 2^{\prime} / \mathrm{S}_{\mathrm{N}} 2$ selectivity: 96/4. e.r $=92: 8(\mathrm{~S}) .[a]_{D}^{20}:+10.5(\mathrm{c}=1$, chloroform $)$ $\left[\right.$ Litt $^{10}:[a]_{D}^{20}=+10.1$ (c $=1$, chloroform), e.r.= 91:9]. Enantiomeric excess was measured by chiral GC: Beta-dex column, helium $(30.9 \mathrm{~cm} / \mathrm{sec}), 80^{\circ} \mathrm{C}-55 \mathrm{~min}-$ $10^{\circ} \mathrm{C} / \min -160^{\circ} \mathrm{C}-10 \min , \mathrm{R}_{\mathrm{t}} 1=43.7 \mathrm{~min}(R), \mathrm{R}_{\mathrm{t}} 2=44.3 \min (S) .{ }^{1} \mathrm{H} \mathrm{NMR}(400 \mathrm{MHz}$, Chloroform-d): $\delta=7.37-7.16(\mathrm{~m}, 5 \mathrm{H}), 6.04(\mathrm{dd}, J=17.4,10.8 \mathrm{~Hz}, 1 \mathrm{H}), 5.10(\mathrm{dd}, J=$ 10.8, $1.4 \mathrm{~Hz}, 1 \mathrm{H}), 5.04(\mathrm{dd}, J=17.4,1.4 \mathrm{~Hz}, 1 \mathrm{H}), 1.90-1.74(\mathrm{~m}, 2 \mathrm{H}), 1.38(\mathrm{~s}, 3 \mathrm{H}$, $\left.\mathrm{CH}_{3}\right), 0.80(\mathrm{t}, J=7.6 \mathrm{~Hz}, 3 \mathrm{H}) .{ }^{13} \mathrm{C}$ NMR $(101 \mathrm{MHz}$, Chloroform-d): $\delta=147.6,147.0$, $128.1,126.8,125.8,111.9,44.7,33.5,24.5,9.0$.

1-bromo-2-(3-methylpent-1-en-3-yl)benzene (11b): Colorless oil (81 mg, 68\%, conversion $>95 \%)$. $S_{N} 2 ' / S_{N} 2$ selectivity: $>98 /<2$. e.r $=91: 9(S) .[a]_{D}^{20}:+1.7(c=1$, chloroform). [ $\operatorname{Litt}^{10}:[a]_{D}^{20}=+2.4$ (c=1, chloroform), e.r. $\left.=95: 5\right]$. Enantiomeric excess was measured by chiral GC: GTA column, helium $(33.2 \mathrm{~cm} / \mathrm{sec}), 80^{\circ} \mathrm{C}-60 \mathrm{~min}-110^{\circ} \mathrm{C}$ $15 \min -1^{\circ} \mathrm{C} / \min -160^{\circ} \mathrm{C}-10 \min -10^{\circ} \mathrm{C} / \min , \mathrm{R}_{\mathrm{t}} 1$ (major) $=94.7 \min (R), \mathrm{R}_{\mathrm{t}} 2$ (minor) $=96.7$ $\min (S) .{ }^{1} \mathrm{H}$ NMR (400 MHz, Chloroform-d) $\delta 7.57$ (dd, $\left.J=7.9,1.4 \mathrm{~Hz}, 1 \mathrm{H}\right), 7.40$ (dd, $J=8.0,1.7 \mathrm{~Hz}, 1 \mathrm{H}), 7.29-7.22(\mathrm{~m}, 1 \mathrm{H}), 7.05(\mathrm{ddd}, J=7.9,7.2,1.7 \mathrm{~Hz}, 1 \mathrm{H}), 6.20$ (dd, 
$J=17.6,10.7 \mathrm{~Hz}, 1 \mathrm{H}), 5.10(\mathrm{dd}, J=10.7,1.1 \mathrm{~Hz}, 1 \mathrm{H}), 4.93(\mathrm{dd}, J=17.6,1.1 \mathrm{~Hz}$, 1H), 2.41-2.29 (m, 1H), 1.94-1.82 (m, 1H), $1.49(\mathrm{~s}, 3 \mathrm{H}), 0.71(\mathrm{t}, J=7.5 \mathrm{~Hz}, 3 \mathrm{H}) .{ }^{13} \mathrm{C}$ NMR (101 MHz, Chloroform-d) $\delta 146.5,145.1,135.6,129.9,127.8,127.0,123.5$, 112.6, 46.4, 31.3, 25.8, 9.1.

1-(3-methylpent-1-en-3-yl)naphthalene (11c): Colorless oil (74 mg, 71\%, conversion $78 \%) . S_{N} 2 ' / S_{N} 2$ selectivity: 96/4. e.r $=95: 5 .[a]_{D}^{20}:-6.5\left(c=1\right.$, chloroform). [Litt ${ }^{10}$ $[a]_{D}^{20}=-8.0(c=1$, chloroform $)$, e.r. $\left.=96: 4\right]$. Enantiomeric excess was measured by chiral HPLC: OJ-H column, hexane $(100 \%)-0.3 \mathrm{~mL} / \mathrm{min}, \lambda=254 \mathrm{~nm}, \mathrm{~T}=25^{\circ} \mathrm{C}$, $\mathrm{R}_{\mathrm{t}} 1$ (minor $)=17.9 \mathrm{~min}, \mathrm{R}_{\mathrm{t}} 2$ (major) $=18.5 \mathrm{~min} .{ }^{1} \mathrm{H} \mathrm{NMR}(400 \mathrm{MHz}$, Chloroform $-d): \delta=$ $8.38(\mathrm{~d}, J=8.6 \mathrm{~Hz}, 1 \mathrm{H}), 7.86-7.83(\mathrm{~m}, 1 \mathrm{H}), 7.74(\mathrm{~d}, J=8.0 \mathrm{~Hz}, 1 \mathrm{H}), 7.50-7.37(\mathrm{~m}$, 4H), $6.32(\mathrm{dd}, J=17.7,10.7 \mathrm{~Hz}, 1 \mathrm{H}), 5.13(\mathrm{~d}, J=10.8 \mathrm{~Hz}, 1 \mathrm{H}), 5.03(\mathrm{~d}, J=17.6 \mathrm{~Hz}$, 1H), 2.35-2.26 (m, 1H), 2.04-1.95 (m, 1H), $1.57(\mathrm{~s}, 3 \mathrm{H}), 0.67(\mathrm{t}, J=7.4 \mathrm{~Hz}, 3 \mathrm{H}) .{ }^{13} \mathrm{C}$ NMR (101 MHz, Chloroform-d) $\delta 149.0,142.5,135.0,131.8,129.2,127.8,127.7$, $125.2,125.1,124.9,124.4,112.1,45.7,32.9,27.5,9.1$.

\section{Acknowledgements}

We are grateful to the CNRS, the Ecole Nationale Supérieure de Chimie de Rennes. This work was supported by Omega Cat System and the region Bretagne (ARED $\mathrm{n}^{\circ} \mathrm{COH} 14007$ "NHC-MET" grant to RT) and the Agence Nationale de la Recherche (NANR-15-CE07-0012-01 "CHADOC"). 
Supporting Information: Detailed spectral data for products, crystallographic data (CIF files) and supplementary experiments, this material is available free of charge via the Internet at http://pubs.acs.org.

\section{References}

(1) (a) For a recent book on NHCs, see: N-Heterocyclic Carbenes: From Laboratory Curiosities to Efficient Synthetic Tools (Eds.: Díez-González, S.), RSC Catalysis series, RSC Publishing: Cambridge, 2011; (b) Hopkinson, M. N.; Richter, C.; Schedler, M.; Glorius, F. Nature 2014, 510, 485.

(2) For a review dealing with NHC/TM in catalysis, see: Gonzalez, S. D.; Marion, N.; Nolan, S. P. Chem. Rev. 2009, 109, 3612.

(3) For a selection of recent examples, see: (a) Valente, C.; Belowich, M. E.; Hadei, N.; Organ, M. G. Eur J.Ora Chem. 2010, 4343. (b) Valente, C.; Pompeo, M.; Sayah, M.; Organ, M. G. Ora. Proc. Dev.Res. 2014, 18, 180. (c) Nelson, D. J.; Queval, P.; Rouen, M.; Magrez, M.; Caijo, F.; Borré, E.; Laurent, I.; Crévisy, C.; Baslé, O.; Mauduit, M.; Percy, J. M. ACS Catal. 2013, 3, 259. (d) Gaillard, S.; Cazin, C. S. J.; Nolan, S. P. Acc. Chem.Res. 2012, 45, 778. (e) Moselage, M.; Sauermann, N.; Ritter, S. C.; Ackermann, L. Anqew. Chem. Int. Ed. 2015, 54, 6352.

(4) Tornatzky, J.; Kannenberg, A.; Blechert, S. Dalton Trans. 2012, 41, 8215.

(5) For selective metathesis reaction, see: (a) Hamad, F. B.; Sun, T.; Xiao, S.; Verpoort, F. Coord Chem.Rev. 2013, 257, 2274. (b) Thomas, R. M.; Keitz, B. K.; Champagne, T. M.; Grubbs, R. H. J. Am. Chem. Soc. 2011, 133, 7490. (c) Rosebrugh, L. E.; Herbert, M. B.; Marx, V. M.; Keitz, B. K.; Grubbs, R. H. J. Am. Chem. Soc. 2013, 135, 1276. (d) Quigley, B. L.; Grubbs, R. H. Chem. Sci. 2014, 5, 501. (e) Mangold, S. L.; O'Leary, D. J.; Grubbs, R. H. J. Am. Chem. Soc. 2014, 136, 
12469. (f) Bronner, S. M.; Herbert, M. B.; Patel, P. R.; Marx, V. M.; Grubbs, R. H. Chem. Sci. 2014, 5, 4091. (g) Herbert, M. B.; Suslick, B. A.; Liu, P.; Zou, L.; Dornan, P. K.; Houk, K. N.; Grubbs, R. H. Orqanometallics 2015, 34, 2858.

(6) For a review dealing with chiral NHC in catalysis, see : (a) Wang, F.; Liu, L.-J.; Wang, W.; Li, S.; Shi, M. Coord.Chem.Rev. 2012, 256, 804. For Copper-Catalyzed Asymmetric C-C bond formation, see : (b) Jennequin, T.; Wencel-Delord, J.; Rix, D.; Daubignard, J.; Crévisy, C.; Mauduit, M. Svnlett 2010, 1661. (c) Magrez, M.; Le Guen, Y.; Baslé, O.; Crévisy, C.; Mauduit, M. Chem. Eur. J. 2013, 19, 1199.

(7) For selected examples using CAAC ligands, see: (a) Lavallo, V.; Canac, Y.; Prasang, C.; Donnadieu, B.; Bertrand, G. Angew. Chem. Int. Ed. 2005, 44, 5705. (b) Kinjo, R.; Donnadieu, B.; Celik, M. A.; Frenking, G.; Bertrand, G. Science 2011, 333, 610. (c) Ung, G.; Rittle, J.; Soleilhavoup, M.; Bertrand, G.; Peters, J. C. Angew. Chem.Int.Ed. 2014, 53, 8427. (d) Marx, V. M.; Sullivan, A. H.; Melaimi, M.; Virgil, S. C.; Keitz, B. K.; Weinberger, D. S.; Bertrand, G.; Grubbs, R. H. Angew. Chem. Int. Ed. 2015, 54, 1919. (e) Hu, X.; Soleilhavoup, M.; Melaimi, M.; Chu, J.; Bertrand, G. Angew.Chem.Int.Ed. 2015, 54, 6008. (f) Jin, L.; Melaimi, M.; Kostenko, A.; Karni, M.; Apeloig, Y.; Moore, C. E.; Rheingold, A. L.; Bertrand, G. Chem. Sci. 2016, 7, 150.

(8) (a) Benhamou, L.; Chardon, E.; Lavigne, G.; Bellemin-Laponnaz, S.; César, V. Chem. Rev. 2011, 111, 2701. (b) Fürstner, A.; Alcarazo, M.; César, V.; Lehmann, C.W. Chem. Commun. 2006, 2176. (c) Katayev, D.; Jia, Y.-X.; Sharma, A. K.; Banerjee, D.; Besnard, C.; Sunij, R. B.; Kündig, P. Chem. Eur. J. 2013, 19, 11916.

(9) Queval, P.; Jahier, C.; Rouen, M.; Artur, I.; Legeay, J.-C.; Falivene, L.; Toupet, L.; Crévisy, C.; Cavallo, L.; Baslé, O.; Mauduit, M. Angew. Chem. Int. Ed. 2013, 52, 14103; Angew. Chem. 2013, 125, 14353. 
(10) Jahier-Diallo, C.; Morin, M. S. T.; Queval, P.; Rouen, M.; Artur, I.; Querard, P.;

Toupet, L.; Crévisy, C.; Baslé, O.; Mauduit, M. Chem.Eur.J. 2015, 21, 993.

(11) (a) Arduengo, A. J.; Krafczyk, R.; Schmutzler, R.; Craig, H. A.; Goerlich, J. R.; Marshall, W. J.; Unverzagt, M. Tetrahedron 1999, 55, 14523. (b) Huang, J.; Nolan, S. P. J.Am. Chem. Soc. 1999, 121, 9889. (c) Hintermann, L. Beilstein J. Org. Chem. 2007, 3, 22.

(12) (a) Jafarpour, L.; Stevens, E. D.; Nolan, S. P. J. Oraanomet. Chem. 2000, 606, 49. (b) Delaude, L.; Szypa, M.; Demonceau, A.; Noels, A. F. Adv. Synth. Catal. 2002, 344, 749. (c) Ogle, J. W.; Zhang, J.; Reibenspies, J. H.; Abboud, K. A.; Miller, S. A. Orq. Lett. 2008, 10, 3677.

(13) (a) Bildstein, B.; Malaun, M.; Kopacka, H.; Wurst, K.; Mitterbock, M.; Ongania, K.-H.; Opromolla, G.; Zanello, P. Oraanometallics 1999, 18, 4325. (b) BerthonGelloz, G.; Siegler, M. A.; Spek, A. L.; Tinant, B.; Reek,; J. N. H.; Marko, I. Dalton Trans. 2010, 39, 1444.

(14) Ahlin, J. S. E.; Donets, P. A.; Cramer, N. Angew. Chem. Int. Ed. 2014, 53, 13229.

(15) Following the previously reported general procedure for the synthesis of unsymmetrical unsaturated imidazolium salts (ref. 9), 3e was prepared with $95 \%$ selectivity and $87 \%$ yield.

(16) See supporting information for details

(17) Preliminary results tend to demonstrate that the equilibration reactions between the three diimines are accelerated in the presence of $\mathrm{ZnCl}_{2}$.

(18) An alternative cyclization mechanism would involve the reaction between diimine $\mathbf{4}$ and the hemiaminal resulting from the addition of $2 \mathbf{e}$ with formaldehyde. 
(19) Mauduit, M.; Basle, O.; Clavier, H.; Crévisy, C.; Denicourt-Nowicki A. in Comprehensive Organic Synthesis II, Vol. 4 (Eds.: Knochel, P.; Molander, G. A.), Elsevier, Amsterdam, 2014, pp. 186.

(20) (a) Lillo, V.; Prieto, A.; Bonet, A.; Diaz-Requejo, M.; Ramirez, J.; Perez, P. J.; Fernandez, E. Oraanometallics 2009, 28, 659. (b) Park, J. K.; Lackey, H. H.; Rexford, M. D.; Kovnir, K.; Shatruk, M.; McQuade, D. T. Ora.Lett. 2010, 12, 5008. (c) O'Brien, J. M.; Lee, K.-S.; Hoveyda A. H. J. Am. Chem. Soc. 2010, 132, 10630. (d) HirschWeil, D.; Abboud, K. A.; Hong, S. Chem. Commun. 2010, 46, 7525. (e) Zhao, L.; Ma, Y.; Duan, W.; He, F.; Chen, J.; Song, C. Ora. Lett. 2012, 14, 5780. (f) Wang, L. Chen;

Z. Ma, M.; Duan, W.; Song, C.; Ma, Y. Org. Biomol. Chem. 2015, 13, 10691. (g) Niu, Z.; Chen, J.; Chen, Z.; Ma, M.; Song, C.; Ma, Y. J. Org. Chem. 2015, 80, 602.

(21) Check, C. T.; Po Jang, K.; Scwamb, B.; Wong, A. S.; Wang, M. H.; Scheidt, K. A. Angew. Chem.Int.Ed. 2015, 54, 4264.

(22) Thangavel, A. ; Wieliczko, M. ; Bacsa, J. ; Scarborough, C. C. Inorg. Chem., 2013, 52,13282

(23) Zhang, J.-L.; Chen, L.-A.; Xu, R.-B.; Wang, C.-F.; Ruan, Y.-P.; Wang, A.E.; Huang, P.-Q. Tetrahedron: Asvmmetry, 2013, 24, 492. 